\title{
Social Media, Celebrity Endorsers and Effect on Purchasing Intentions of Young Adults
}

Kaitlin M. Davis

Follow this and additional works at: https://researchrepository.wvu.edu/etd

\section{Recommended Citation}

Davis, Kaitlin M., "Social Media, Celebrity Endorsers and Effect on Purchasing Intentions of Young Adults" (2017). Graduate Theses, Dissertations, and Problem Reports. 7319.

https://researchrepository.wvu.edu/etd/7319

This Thesis is protected by copyright and/or related rights. It has been brought to you by the The Research Repository @ WVU with permission from the rights-holder(s). You are free to use this Thesis in any way that is permitted by the copyright and related rights legislation that applies to your use. For other uses you must obtain permission from the rights-holder(s) directly, unless additional rights are indicated by a Creative Commons license in the record and/ or on the work itself. This Thesis has been accepted for inclusion in WVU Graduate Theses, Dissertations, and Problem Reports collection by an authorized administrator of The Research Repository @ WVU. For more information, please contact researchrepository@mail.wvu.edu. 
Social Media, Celebrity Endorsers and Effect on Purchasing Intentions of Young Adults

\author{
Kaitlin M. Davis \\ Thesis submitted to the \\ Reed College of Media \\ at West Virginia University \\ in partial fulfillment of the requirements for the degree of \\ Master of Science in \\ Journalism
}

Steve Urbanski, Ph.D., Chair

Tom Stewart, M.S.J

Catherine Mezera, M.S.

Nicholas Bowman, Ph.D.

Department of Journalism

Morgantown, West Virginia

2017

Keywords: Celebrity Endorsement, Source Attractiveness, Source Credibility, Millennials, Millennials' Social Media Use, Survey Methodology

Copyright 2017 Kaitlin Davis 
ProQuest Number: 10275057

All rights reserved

INFORMATION TO ALL USERS

The quality of this reproduction is dependent upon the quality of the copy submitted.

In the unlikely event that the author did not send a complete manuscript and there are missing pages, these will be noted. Also, if material had to be removed, a note will indicate the deletion.

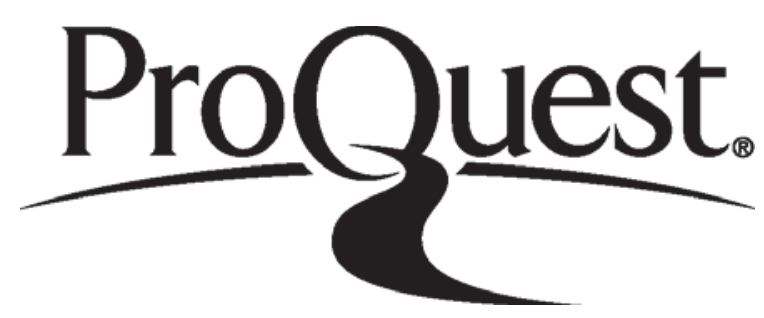

ProQuest 10275057

Published by ProQuest LLC (2017). Copyright of the Dissertation is held by the Author.

All rights reserved.

This work is protected against unauthorized copying under Title 17, United States Code Microform Edition (C) ProQuest LLC.

ProQuest LLC.

789 East Eisenhower Parkway

P.O. Box 1346

Ann Arbor, Ml $48106-1346$ 


\begin{abstract}
Social Media, Celebrity Endorsers and Effect on Purchasing Intentions of Young Adults
\end{abstract}

\begin{abstract}
Kaitlin M. Davis
Through an online survey methodology, this study explored how the relationship between the three celebrity-based characteristics - trustworthiness, attractiveness and expertise - and Millennials' social media usage influences Millennials' purchasing intentions, or their likelihood to buy the product or brand being endorsed. Millennials were the focus of this study due to their involvement with social media, their pre-existing parasocial interactions with celebrities on social media and their increased likelihood of buying products endorsed by celebrities with the hope of being more like them.

The most significant finding revealed that the three celebrity-based characteristics - expertise, trustworthiness and attractiveness - are perceived differently by Millennials when compared to past research. Results showed that the respondents viewed the characteristics as one combined variable due to high correlations between the three. Millennial participants may have been affected by the halo effect and the cognitive consistency theory, which both work together to explain that Millennials who view celebrities as nice or positive will rate the rest of their characteristics positively. If a Millennial views the celebrity as negative, their characteristics will be rated negatively. Furthermore, the results indicated that Millennials' social media usage has more of an impact on Millennials' purchasing intentions, meaning that Millennials' who have higher levels of social media use are more likely to purchase from the brand or buy the product being endorsed.
\end{abstract}

These findings highlight the differing perceptions of Millennials in regard the celebrity characteristic. Furthermore, the findings also show how Millennials' social media use affects their purchasing intentions. With this change in perceptions, this study can help expand the knowledge and practices of brands and companies choosing celebrities to endorse their brand. 


\section{Dedication}

I want to dedicate this thesis to my father, Thomas Wayne Davis, who unfortunately passed away in January 2012, and who hasn't been here on earth to see me accomplish this. He has shaped me tremendously in my personal and professional life. I know he would be proud of the work that I've done, and it's because of him that I continue to push myself to succeed. 


\section{Acknowledgements}

I would first like to thank the members of my committee who have helped shape my thesis into what it is today. Dr. Steve Urbanski, the chair of my committee, Professor Tom Stewart and Professor Catherine Mezera, all at the Reed College of Media at West Virginia University (WVU), supported me throughout this process alongside Dr. Nicholas Bowman at the Department of Communication Studies at WVU. The doors to each one of my committee members was always open whenever I ran into a trouble spot, needed help with my research or my writing or needed a word of encouragement. Without their help and guidance, this process wouldn't have been easy, and I am thankful that I had a wonderful committee that supported me.

In addition, I would like to also thank Dr. Geah Pressgrove, assistant professor at the Reed College of Media at WVU, for her support, encouragement and guidance. I couldn't have asked to work for a better professor, and she always pushed me to challenge myself. She was willing to take time out of her day to look at my data or any of my other thesis materials whenever I was unsure of anything. In addition to my committee, she made the road to finish my thesis smooth.

Finally, I must express my profound gratitude to my family and friends who have continuously supported me and encouraged me as I followed my dreams and through the process of researching and writing this thesis. I couldn't have completed this thesis without them.

Thank you for all the support and encouragement. 


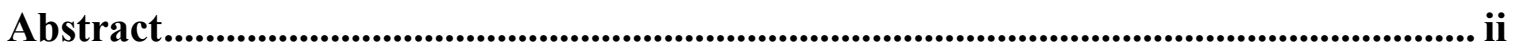

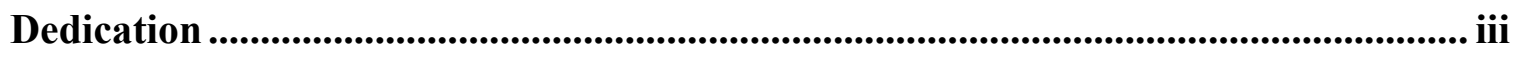

Acknowledgements ................................................................................................................. iv

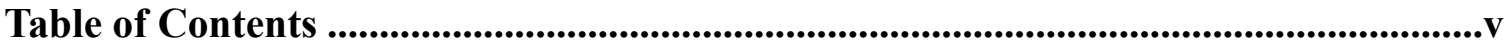

List of Tables and Figures ........................................................................................ vi

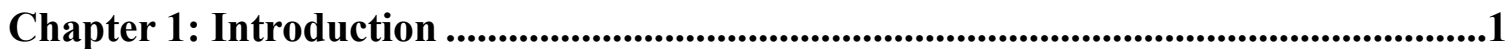

Chapter 2: Literature Review .............................................................................5

2.1 Social Effect Theory, Source Credibility and Source Attractiveness Model ......5

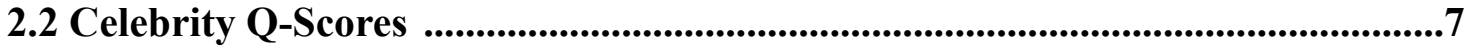

2.3 Match-up Hypothesis ...................................................................................................9

2.4 Meaning Transfer Model...............................................................................................14

2.5 Millennials: Social Media Use \& Celebrity Influence ......................................16

2.6 Purchase Intention ..........................................................................................................19

Chapter 3: Hypotheses ...............................................................................................21

Chapter 4: Methodology....................................................................................................23

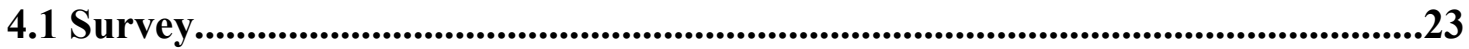

4.2 Survey Measures ..............................................................................................24

4.2.1 Source credibility and source attractiveness (expertise, trustworthiness

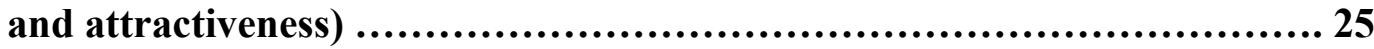

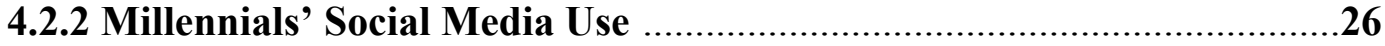

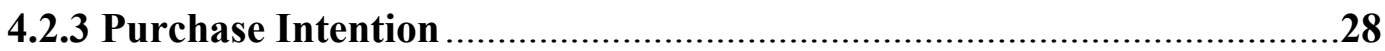

4.3 Analysis Process....................................................... 30

Chapter 5: Results.........................................................................................................33

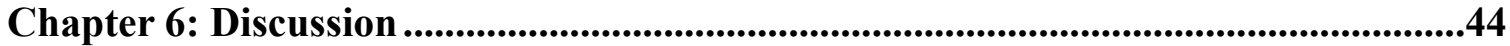

6.1 Findings and Implications ................................................................................45

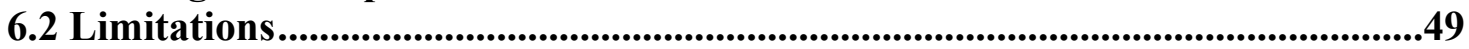

6.3 Future Research .....................................................................................51

Chapter 7: Conclusion .....................................................................................................................55

References .........................................................................................................................57

Appendices..............................................................................................................................667

Appendix A: IRB Approval Letter ...............................................................................67

Appendix B: Email Informed Consent Statement ................................................69

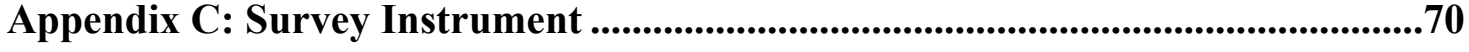




\section{List of Tables and Figures}

Figure 1 Hypotheses and Associated Statistics Tests .............................................. 31

Figure 2 Histogram for Celebrity Characteristics Combined ........................................42

Table 1 Descriptive Statistics for Respondent's Demographic Variables .................36

Table 2 Means, Standard Deviations Skewness, Kurtosis and Reliability for Key

Variables................................................................ 38

Table 3 Means, Standard Deviations and Reliability Coefficients for Purchasing

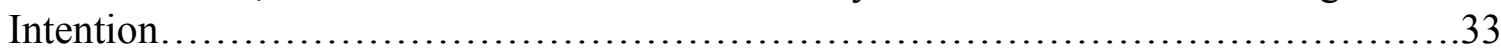

Table 4 Means, Standard Deviations, Skewness and Kurtosis for Combined Celebrity

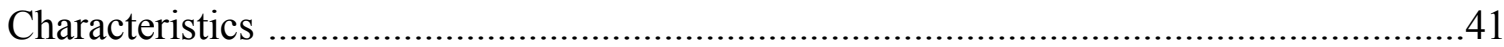

Table 5 Means, Standard Deviations, and Intercorrelations for Millennial's Purchasing Intentions and Predictor Variables 39

Table 6 Hierarchical Multiple Regression Analysis Summary Predicting Millennials' Social Media Use from the Celebrity Characteristics (Expertise, Attractiveness and Trustworthiness) 
Social Media, Celebrity Endorsers and Effect on Purchasing Intentions of Young Adults

\section{Chapter 1: Introduction}

Celebrity-based advertisements are popular in today's society and can be seen on television daily. From Alec Baldwin promoting Capital One Bank to Adam Levine promoting Proactiv and various female celebrities promoting makeup products, avoiding such marketing techniques and advertisements can be difficult. Of the many American commercials that we encounter on a day-to-day basis, 25 percent use celebrity endorsers (Silvera \& Austad, 2004). Endorsement payments for celebrities have been as high as $\$ 45$ million in 1998 for Michael Jordan, \$25 million for Tiger Woods, \$17 million for Grant Hill, and \$10 million for Shaquille O'Neal (Daneshvary \& Schwer, 2000). Age demographics play a major role in how a consumer is influenced by celebrity-based endorsements. Young adults and adolescents, specifically, may be influenced somewhat more due to their involvement in celebrities' lives through social media. Using different source credibility measures, such as attractiveness, expertise and trustworthiness, marketers use celebrities to influence our purchasing intentions; however, studies have shown an association between adolescents' involvement with celebrities and their product purchases (Chia \& Yip Ling, 2009). This thesis focuses on the attractiveness, expertise and trustworthiness of the celebrity used in a given advertisement and how Millennials' social media use affects their purchasing intentions. Young adults often have parasocial relationships with their favorite celebrities through social media, and therefore, look up to them and follow their every move. Because of that behavior and their overall social 
media use, young adults may be more susceptible to having their purchasing intentions affected when their favorite celebrities are endorsing products and are telling their audience how great the products are.

Celebrity endorsements are not a recent development but have grown in popularity since the late nineteenth century (Erdogan, 1999). McCracken (1989) defined a celebrity endorser as an individual who enjoys public recognition and who uses that public recognition in coordination with a consumer good in an advertisement. Companies spend money to align their brands with endorsers who are seen as dynamic and attractive. In addition, celebrities are seen as individuals with likeable qualities (Erdogan, 1999). As a result, companies use celebrities' positive qualities to endorse their own brand and products. Celebrities, through their fame, serve not only to create and maintain society's attention but also to create a natural association within consumers' minds between a brand or product and the celebrity who endorses that product. The same can be said for when an individual thinks of a celebrity first. Celebrity endorsements influence advertising effectiveness, brand recognition, brand recall, a consumer's purchase intentions and his or her purchase behavior (Spry, Pappu \& Cornwell, 2011). Celebrities also can boost awareness of a product and create more appeal (Money, Shrimp \& Sakano, 2006). Since celebrity endorsements do have an impact on those aspects of the advertisement and the consumer, it is that important the advertisers choose celebrities effectively, which is where source credibility measures come into action.

Source attractiveness, as defined by Silvera \& Austad (2004), is more generally a positive attitude that a receiver has toward an endorser rather than a said endorser's 
physical attractiveness. Physical attractiveness, however, is one important cue used by an individual in order to make judgments about another person. Till \& Bustler (2000) and others have found that physically attractive models used in advertising have led to a more-favorable attitude toward the advertisement. Though physical attractiveness does play a role in receivers' attitudes toward brands and their purchasing intentions, expertise is believed to be a factor that increases the persuasiveness of a celebrity-based advertisement beyond that of trustworthiness (Silvera \& Austad, 2004). Expertise refers to the product knowledge of the endorser and the validity of the claims made in the advertisement (Silvera \& Austad, 2004). The idea of expertise also has been referred to as authoritativeness, competence, expertness and qualification by other researchers who have examined the concept. The third concept, trustworthiness, is the general believability of the endorser (Silvera \& Austad, 2004). Trust in the communication from the endorser to the receiver comes from the receiver's degree of confidence in and the level of acceptance of the message from the endorser (Ohanian, 1990).

Though these three characteristics are seemingly quite different, their effectiveness has been tested against the match-up hypothesis, which states that endorsers are more effective when there is a fit between endorser and endorsed product (Till \& Busler, 2000). The conceptual argument as mentioned by Till and Busler is that attractive celebrities are more effective endorsers for products that make the endorser appear more attractive, leading to high brand attitudes and purchase intentions. Early research into the match-up hypothesis found that effectiveness varied by product. Kanungo and Pang (1973) paired males and females with specific products and found that their effectiveness 
depended on which product was paired with the individual. To describe the "fit" between the endorser and the product, the match-up hypothesis was used. The main purpose of the proposed study was to expand on the advertising literature that examines the three characteristics of expertise, trustworthiness and attractiveness and their effectiveness within advertisements using the match-up hypothesis. Many of the studies found in the literature review focused more on the attractiveness of the endorsers as opposed to their expertise or trustworthiness.

Among the age categories who may be influenced more by a given celebrity advertisement are Millennials because of their involvement with celebrities on social media. The birth years of Millennials has varied from 1980 to 1995 and 1980 to 2004 (McCormick, 2016). However, regardless of the debate surrounding the age range, the Pew Research Center has identified the Millennial generation as anyone born after 1980, and the cohort is 80 million strong (McCormick, 2016). Through mass and social media, those in that age demographic are able to keep up with their favorite celebrities. Adolescents and young adults often have parasocial relationships with celebrities, meaning, "imaginary relationships and sense of intimacy that media consumers develop with media characters" (Chia \& Yip Ling, 2009, p. 24). Identification is also an important part of their involvement with a celebrity. Adolescents and young adults reach identification when an individual imitates a celebrity through his or her dress, behavior or purchases as a way of maintaining a relationship with that celebrity (Chia \& Yip Ling, 2009). Granted, the said celebrity has no knowledge of this "friendship," but the young adult consumer feels as though there is a relationship or connection. Levy (1979) 
explained that media characters encourage a parasocial relationship by speaking in conversational tones in advertisements, by speaking in a manner that appears to require audience reciprocity and by casually communicating on media platforms. Celebrities appeal to young adults and adolescents, and those individuals want to be involved in their lives. They often see celebrities as their role models and try to imitate many of the celebrity's behaviors. According to Chant et al., (2013), various role models, including entertainers and athletes, have been shown to influence young adults' purchasing intentions and behaviors (p. 8).

\section{Chapter 2: Literature Review}

\subsection{Social Effect Theory, Source Credibility and Source Attractiveness Model}

Looking at O’Mahony \& Meenghan's (1998) research on the effects of celebrity-based advertising on receivers, results from their study indicate that receivers have an overall positive attitude toward celebrity-based endorsements. Such advertisements are seen as "attention-gaining, likeable, and impactful" (p.15). The celebrity phenomenon has invaded our society, media and culture within the past century due to western secularization or perhaps due to the superiority celebrities have in society's eyes. Individuals follow them on various social media sites to keep up to date on their latest doings and to communicate with them, even if it is only one-way communication. Modern corporations are aware of society's feelings toward celebrities, and as a result corporations invest millions of dollars into aligning their products with big-name celebrities (O’Mahony \& Meenghan, 1998). Nike alone reported in 2015 that it would have $\$ 3.2$ billion worth of endorsement deals over the next five years, according to 
Thomas and Fowler (2015). Corporations do so in order to draw attention to their endorsed product as well as transfer image values held by the endorser to the product or service. In order to choose the appropriate characteristics of celebrities to create a positive effect on receivers, corporations can study the source-effect theory, which is a conceptual framework that theorizes how celebrities in advertisements affect receivers (O’Mahony \& Meenghan, 1998). For the proposed study, source-effect theory is essential to understanding the three characteristics chosen (attractiveness, trustworthiness and expertise) and how corporations can pick the right celebrity with the right characteristics to influence consumers to purchase the product the celebrity is endorsing. Various source attributes have been used within this theory to explain the effectiveness of the communication of the source, but two main models are used; the source credibility and the source attractiveness model (O’Mahony \& Meengha, 1998).

Ohanian (1990) addressed these two models within his research. When looking at the ideas of expertise, trustworthiness and attractiveness, these three attributes fall under these two models. The source credibility model shows that the factors showing the credibility of the source, specifically expertise and trustworthiness, emphasize the concept of source credibility (p. 41). An endorsers' credibility is measured in high and low levels of credibility or expertise, with high-credibility advertisements being the most influential. Those advertisements with endorsers who have high credibility tend to receive more positive attitudes from receivers toward the endorser and advertisement along with more behavioral compliance from receivers (Pornpitakpan, 2004). High and low rates of credibility within an advertisement influence a receiver's intention to follow 
the suggestions made by the endorser and whether or not the suggestions given by the endorser are accepted or rejected. Pornpitakpan (2004) also stated that source credibility was found to have a direct effect on how receivers are persuaded and how they respond behaviorally.

The second model, as talked about by Ohanian (1990) and O'Mahony \& Meengha (1998), is the source attractiveness model. The two characteristics associated with the source attractiveness model are likeability and similarity. As defined by Ohanian (1990), likeability is the presence or absence of feelings the receiver has toward a source of information or endorser. Attractive people are generally viewed as not only more likeable and favorable in the eyes of society, but they also must be similar to the target audience. The more the receiver feels that the source is similar to her or him in terms of attitudes, opinions, activities, background, social status or lifestyle, the more likely the receiver will be influenced by the endorser's message (Ohanian, 1990). Physical attractiveness also has been found to significantly enhance communicator effectiveness (Chaiken, 1979).

\subsection{Celebrity Q-Scores}

In addition to looking at source credibility and source attractiveness, brands and companies also need to think about endorsers' Q-scores, or Q-ratings, which stands for quotient rating (Kahle \& Kahle, 2006). The basic question that lies behind the idea of

these scores is, "How appealing is the person among those who do know him or her?" (Patra \& Dalta, 2012, p. 52). Celebrity endorsements can be expensive, and marketers must rely on these rating systems to evaluate the potential value attained by certain celebrity endorsers. Q-scores are determined by Marketing Evaluations/TVQ and are 
meant to provide knowledge to firms who are looking at a particular celebrity for a specific target audience (Kahle \& Kahle, 2006). There are two types of Q-ratings that are examined by the company: performer Q-ratings and sport Q-ratings, both of which come out with updates every January and July ("How can we help?," 2017). With 1,500 celebrities examined annually, the two categories of Q-ratings help to better target specific markets (Shanklin \& Miciak, 1997). These 1,500 celebrities include performers, personalities, celebrities, characters, sports and sports personalities, broadcast and cable programs as well as company and brand names (Costanzo \& Goodnight, 2006; Shanklin \& Miciak, 1997).

For the 1,500 celebrities being scored, surveys are sent to a representative sample, or the Market Evaluations Panel, of individuals between the ages of 12 and 65 to analyze the Q-rating of the celebrity in question. Two factors contribute to the calculation of the ratings: familiarity (f) and popularity (p). Familiarly is based on whether or not someone has heard of the celebrity before, while popularity is based on rating the celebrity as "poor, fair, good or one of my favorites," (Kahle \& Kahle, 2006, p. 192). The final Qscore is determined by dividing the percentage of panel members who select the celebrity as one of their favorites by the percentage of panel members who had said they had heard of the celeb, in other words $\mathrm{p}$ percentage/f percentage $=$ Q-rating. However, Kahle and Kahle (2006) argue that while the Q-rating system has been around for decades and is easy to collect, one big flaw exists - the way popularity is calculated. Popularity is only included in the final Q-score if a panel member selects the celebrity as one of his or her favorites. 
Past research has looked more specifically at sport celebrities and how marketers can use their Q-scores in combination with other variables to pick the right celebrity for the right advertisement (Kahle \& Kahle, 2006; Shanklin \& Miciak, 1997; Badenhausen, 2016), but some researchers have taken the magazine route (Costanzo \& Goodnight, 2006; Belch \& Belch, 2013). It makes sense that past research would be focused on sports because 350 out of the 1,500 celebrities measured are athletes, and most athletes appeal to closely defined target audiences (Shanklin \& Miciak, 1997). Based on Badenhausen's (2016) article for Forbes, the top ten most marketable athletes in 2015 included Payton Manning, Michael Phelps, Simone Biles, Serena Williams and LeBron James, all in the top five. Payton Manning's Q-score ranked at number 75 overall with his awareness level ranking in the top $2 \%$ and likability in the top $7 \%$ following the Denver Bronco's win over the Carolina Panthers in the 2016 Super Bowl (Badenhausen, 2016). In comparison, Wallenstein (2016) found Q-scores for digital and traditional celebrities based on the perceptions of teens. Pentatonix, an a cappella group, and Ryan Higa, a YouTube comedian, tied for first with a positive rating of 30 , while the traditional ratings for traditional celebrities ranged from Tom Hanks with a positive score of 46 to Beyoncé who had a positive score of 32 (Wallenstein, 2016). Overall, Q-scores for all types of celebrities help marketers evaluate the potential added value of using celebrity endorsers.

\subsection{Match-up Hypothesis}

When looking at source attractiveness, expertise and trustworthiness, other theories and models are used besides the source credibility and source attractiveness 
model. The match-up hypothesis states that endorsers are more effective when there is a fit between endorser and the endorsed product (Till \& Busler, 2000). The match-up hypothesis suggests that visual imagery, in other words the use of a celebrity, contained in a given advertisement conveys more information than does a verbal message (McCormick, 2016). When using a celebrity, the overall effectiveness of the celebrity endorsement is affected by the qualities the celebrity possesses, and his or her qualities are then passed on to the endorsed product. Essentially, brands should pick those celebrities who fit with the associations that the brand currently has, and if picked effectively, the celebrity should create and reinforce those existing associations through the advertisement. Consumers are already going to have pre-existing knowledge and attitudes toward the celebrity. Millennials especially follow all their favorite celebrities on various social media sites, and it's crucial for brands that consumers have a positive attitude toward the celebrity prior to a brand using him or her in an endorsement. Most of the research within this hypothesis has looked primarily at attractiveness as the main independent variable, leaving expertise of the source somewhat unstudied. Physical attractiveness has been presented as a match-up factor when pairing celebrities to advertisements (Kahle \& Homer, 1985). However, expertise has also been considered when looking at match-up effects by researchers such as Ohanian (1990), who conducted two separate studies looking at the effectiveness of physical attractiveness and expertise as match-up factors. Despite all of the studies that follow, the current study took the three attributes that have been studied (attractiveness, expertise and trustworthiness) and the match-up hypothesis while examining the direct effect on Millennials and their purchase 
intentions. Recent research (McCormick, 2016) has examined Millennials and the matchup hypothesis, but in relation to unfamiliar celebrities and their effect on Millennials' purchase intentions, their attitude toward the advertised product and the brand. The current study went beyond that to add in the three attributes with the match-up hypothesis in coordination with Millennials' social media use and how their purchasing intentions are affected.

Ohanian (1990) did also look into trustworthiness of a celebrity and how that affects the persuasiveness of the advertisement as a whole. Looking at previous research by Miller and Baseheart (1969), results from their study indicated that when the communicator had high trustworthiness, an opinioned message was more effective in creating an attitude change (Ohanian, 1990). However, when the communicator was low in trustworthiness, the relationship between the trustworthiness and the persuasiveness of the message was not significant (Ohanian, 1990). The findings of Miller and Baseheart (1969) showed that a source who was perceived to be both an expert and trustworthy caused the most change in attitude. Furthermore, Ohanian (1990) also discussed several studies (Friedman \& Friedman, 1976; Friedman, Santeramo \& Traina, 1979) and how these studies showed that celebrities who are liked will also be trusted by the public. Also, these studies showed that celebrity trustworthiness is highly correlated with a consumer or respondent's similarity to the source, the expertise of the source and the attractiveness of the source.

Kahle and Homer (1985) and Kamins (1990) conducted two research studies highlighting the match between endorsers and products. The match-up hypothesis 
predicts that endorsers who are viewed as attractive will be more effective when they are endorsing products used to enhance their own attractiveness. Kamins (1990) explored this idea by pairing an attractive and unattractive celebrity with a product that may or may not have enhanced the celebrity's attractiveness. The two celebrities used in this case were Tom Selleck and Telly Savalas. Selleck, the attractive celebrity in Kamins' (1990) study, was paired with both a luxury car and a home computer to test the match-up hypothesis. Savalas, the unattractive celebrity, was also paired with both products, and data on seven dependent measures was collected. The seven measures, as laid out by Kamins, were advertiser believability, advertiser credibility, spokesperson believability, spokesperson credibility, brand attitude, attitude toward the ad and purchase intention (Till \& Busler, 2000). Kamins' results showed that for only two out of the seven dependent variables tested, attractiveness was an effective match-up factor, but brand attitude and purchase intentions were not the two out of the seven where attractiveness was effective (Till \& Busler, 2000).

When trying to understand the concept of the match-up hypothesis, Till and Busler (2000) emphasized another theory, the associative learning theory, which is the process by which a link between two separate concepts is established. Memory is structured as an associative network, and the parts making up this associative network include "a set of processing units (nodes), a state of activity, a pattern of connectivity among units, and a learning rule that allows patterns of connectivity to be modified based on experience" (Till, 1998, p. 2). Celebrities and brands are the nodes in the network, and whenever the audience views one of their advertisements, an associative link is made 
between the brand and the endorser. Following the building of the link, the brand and the celebrity become a part of one another's association set. In other words, every time the audience sees either the brand or the celebrity, they associate the one with the other. Till (1998) gives the example of Nike's use of Michael Jordan as an endorser. Whenever consumers think of Michael Jordan, they also think of Nike or vice versa. Nike and Michael Jordan have become a part of each other's association sets. Our attitudes and evaluation of the brand and celebrity are considered an element of our own association sets also (Till \& Busler, 2000).

Fit is an important variable that explains how easily an associative link can be built (Till \& Busler, 2000). The more similar two concepts are, the more they will become one in an associative network. The connection between a brand and an endorser is what drives predicted endorser effects. Lynch and Schuler (1994) conducted a more recent study on the match-up hypothesis by using the muscularity of an individual and how celebrity expertise of exercise equipment affects the audience's view on the advertisement. They did not find, however, that using a muscular versus a non-muscular spokesperson had a major effect on perceptions of the product (Lynch \& Schuler, 1994).

In contrast, Till and Busler's (2000) two studies showed that expertise was possibly more important than physical attractiveness when matching a brand with an appropriate endorser. Their second study used two different product categories, candy bars and energy bars, and they created an endorser, Ted Franklin, who was either a stage and screen actor or a U.S. Olympic track and field athlete (Till \& Busler, 2000). After conducting the study on 213 student subjects, the data revealed that the expertise means, 
as laid out in one of the tables, was significant in comparison to attractiveness and trustworthiness. The brand attitude toward the candy bar in the second study showed there was no significant difference in brand attitude for the athlete or actor. However, the energy bar brand attitude was significantly higher when Ted Franklin was perceived as an athlete then when he was perceived as an actor (Till \& Busler, 2000). Till and Busler (2000) also presented the means for the appropriateness of the endorser for Toba, the brand name given to the candy bar and to the energy bar, along with the degree to which subjects felt that Toba and Ted Franklin were a good fit. The results suggested that an athlete such as Ted Franklin was the best fit for endorsing the Toba energy bar.

\subsection{Meaning Transfer Model}

Celebrity endorsers have the ability to transfer the meanings associated with them onto the product or brand they are endorsing. Celebrity meanings include class, status, gender, age, personality and lifestyle distinctions (McCracken, 1989). For example, Audrey Hepburn is perceived as a regal lady and Pierce Brosnan is characterized as a perfect gentleman. These various distinctions allow for marketers and advertisers to use various combinations that work best with their brand and product. The meaning transfer model is defined by Schlect (2003) as "the effectiveness of celebrity spokespersons by assessing the meanings consumers associate with the endorser and eventually transfer to the brand" (p. 7). McCracken (1989), who developed the model, emphasized that celebrities contain a wide range of meanings (Schlecht, 2003). The meaning transfer model is composed of three stages. In the first stage, the meanings associated with the celebrity are identified and then move from the endorser to the product or brand. As a 
result of identifying and associating meanings with the celebrity, those same meanings become associated in the consumer's mind (Schlecht, 2003). The final step in the meaning transfer model is the consumption process whereby the consumer obtains the brand's meaning. According to Schlecht (2003), this last step is pivotal due to the consumer's role in supporting brands with celebrity endorsers. Celebrity endorsers are effective tools in markets because they provide a set of meanings or characteristics that help consumers to evaluate their feelings toward the brand or product (Martin, 1996, p. 29). McCracken (1989) further adds that celebrities add extra depth and power to the transfer process. When considering what meanings to look for within a celebrity, an advertiser has to pick the celebrity who has the appropriate set of characteristics and who will elicit the correct response from consumers.

As mentioned, the meaning transfer model has three stages that complete the transfer of celebrity meanings to the endorsed product. The first step occurs when meanings from the celebrity (i.e., status, age, class, etc.) are transferred onto the product or brand. (Schlecht, 2003). Celebrities are able to own the meanings they possess because they have created them in such a public setting, as opposed to a model or actor who merely acts out such meanings within an advertisement. The celebrity meanings are also powerful because of the celebrity's career in television, movies, the military or other venues (McCracken, 1989). Their careers are basically large ads that show the world who they are, what meanings they hold and what they can show with those meanings. The second stage in the model occurs when "meaning attributed to the celebrity becomes associated with the brand in the consumer's mind" (Schlecht, 2003, p. 7). Upon choosing 
a celebrity for the endorsement, an advertising company must identify the celebrity meanings and deliver them to the product. The advertisement must also show the similarity between the celebrity and the product so that the consumer will be able to move on to the next step, which is the consumption process. The consumption process is when the brand's meaning is obtained by the consumer (Schlecht, 2003). Consumers play a vital role in this last step of the model because celebrities are self-constructed and consumers are taking meaning from consumer goods and implementing them into their own lives.

\subsection{Millennials: Social Media Use \& Celebrity Influence}

Millennials, or Generation Y, account for 21 to $26 \%$ of the population, according to McCormick (2016). Individuals in this generation tend to use social media and other internet-based affordances more in comparison to older generations. $73 \%$ of wired American teens use some form of a social networking site, and 93\% of 12 - to 17 -yearolds and young adults (18- to 29-year-olds) are online (Lenhart, Purcell, Smith \& Zickuhr, 2010). Social networking sites, such as Twitter and Facebook, are popular among Millennials because these sites allow users to become the producers and stars of their own production through the creation of their content and allow for individuals to invite others to become their friends while also allowing for freedom of choice of who can be their friend (Bergman, Fearrington, Davenport \& Bergman, 2011). The main use of social networking sites among Millennials is to communicate with others and to retrieve information. However, social networking site users also post comments, update their statuses, post photos and videos and message other individuals. Millennials also do 
this with celebrities to build and maintain their parasocial interaction or connection with celebrities. According to Botterill, Bredin and Dun (2015), Millennials are the "vanguards of internet and wireless use" (p. 3). Millennials not only have high percentages of use with social networking sites, but many are checking these sites at least once daily. More specifically, $70 \%$ go online daily and $46 \%$ go on multiple times a day (Lenhart, Madden, Smith, Purcell, Zickuhr \& Rainie, 2011).

In addition, these young adults account for 33 to $35 \%$ of retail spending in a market that is worth $\$ 250$ billion (McCormick, 2016). Through the use of celebrities within advertisements, brands are able to use the celebrity's fame to create a positive effect on consumers' brand awareness, brand trust and brand preference as well as their purchase intentions (Hung et al., 2001). As a celebrity's exposure grows, consumers become more familiar with renowned figures seen in the media, and therefore form a parasocial relationship with the celebrity as they are repeatedly exposed to a celebrity through endorsements and social media postings. A celebrity is often viewed as a hero, role model or another world figure who allows followers to achieve a higher existence (Hung et al., 2001). With mass media, young adults are able to follow their favorite celebrities on various forms of social media and their newest adventures to the point where they feel as though they are a part of it. Individuals invest in these parasocial relationships with their favorite celebrities in the same way that they invest in relationships with those in their everyday lives (Boom \& Lomore, 2001). Emotional connections are made to these celebrities without actually having a face-to-face relationship or face-to-face interactions. It has also been found that a celebrity 
endorsement makes the given product more socially prominent, and this, as result, helps Millennials make a statement about themselves through their consumption of the given product (McCormick, 2016). America is already viewed as a materialistic society; however, Millennials are concerned with their materialism and what others think of them moreso than their parents. As a result, Millennials are more involved with their purchases because of the social consequences that may come about if they make the wrong purchase. Millennials want to fit in and want to be wearing or consuming what is considered acceptable by their peers. Those individuals in the Millennial generation seek out the products that reflect or relate to their own self-image (McCormick, 2016). If an endorser appears in those advertisements for products that match their self-image, then Millennials are more likely to be persuaded to buy the product, especially if the celebrity connects with his or her audience.

Young adults in the Millennial generation are twice as likely as Generation X to be influenced by celebrities and four times more likely than Baby Boomers, according to McCormick (2016). Young adults have been seen to change their physical appearance, abilities, values, attitudes and overall lifestyle in order to align their lives to their favorite celebrity. Celebrity idols help to "inspire efforts at self-transformation that affect, in profound and meaningful ways, many different areas of admirers' lives" (Boom \& Lomore, 2001, p. 435). Individuals grow attached to their favorite celebrities to the point where significant events in the celebrity's life affect the emotional well-being of the individual because they feel those significant events are their own. An important 
theoretical construct that occurs when individuals adopt the values and behaviors of media personae is identification (Fraser \& Brown, 2002).

Identification, as defined by Kelman (1958), is the process by which someone wants to be like or actually be the celebrity. Marketing professionals and advertisers are aware of the effect that celebrities have on people's lifestyles and therefore use celebrities to sell products and services. Nike is one large company that is known for using Michael Jordan as an endorser within its commercials alongside the slogan, "I want to be like Mike," to get the audience to buy the endorsed product (Fraser \& Brown, 2002). The attractiveness of Michael Jordan, his expertise about the product and the trustworthiness he holds all help to influence consumer behavior. Celebrities have also been used to promote social behaviors such as Magic Johnson's promotion of HIV Prevention (Brown \& Basil, 1995; Casey et al., 2003) or Michelle Obama's famous Let's Move campaign (Georgiadis, 2013; Wojcicki, Heyman, 2010). Other campaigns run by companies focus more on Millennials' social media usage, such as Nordstrom, which began pinning footwear in the shoe department with pins that show the shoes' popularity on Pinterest (McCormick, 2016). Barney's New York has also taken the social media popularity among Millennials and has teamed up with Instagram. When consumers follow Barney’s official Instagram feed, consumers can simply click on the link in their profiles to shop at Barney's New York.

\subsection{Purchasing Intention}

The main goal of marketing and advertising companies is to get consumers to purchase their products, and this study sought to understand how the three characteristics 
of attractiveness, trustworthiness and expertise work with Millennials' social media use to influence their purchasing intentions. Purchasing intention has been defined as "a transaction behavior consumers tend to exhibit after evaluating a product, and adopted consumer reaction to a product to measure consumer purchase likelihood" (Wang, Cheng \& Chu, 2013, p. 359). Several studies have examined the effect endorsers have on consumers' purchasing intentions (Gardner \& Shuman, 1986; Kahle \& Homer, 1985; Tripp et al., 1994; Pradhan, Duraipandian \& Sethi, 2016). A positive influence has been found on purchase intention when consumers understand and feel positively toward a given endorsement (Lafferty \& Goldsmith, 1999). The higher the purchasing intention of a consumer, the more he or she is likely to purchase the product being advertised. From a marketer's or advertiser's perspective, a consumer's purchasing intention is a crucial aspect of how effective the celebrity-based endorsement is.

The Theory of Reasoned Action, which was originally explained by Ajzen (1985), suggests that purchase intentions are the result of a link between attitudes and behaviors. This theory is one of the most commonly applied theories within consumer research (Manning, 2009), and consumers must have the thought or intention to purchase a product before they actually perform the action of purchasing that product. Celebrities can influence the consumer through any of the three characteristics discussed in the source credibility and source attractiveness model. Once the celebrity is seen in an advertisement, it is the attitude of the consumer toward the brand, the advertisement and the celebrity that helps the consumer to decide if he or she intends to perform the purchasing behavior. Purchasing intention is important to the study at hand because the 
three characteristics of the celebrity in a given advertisement can have an effect on how consumers feel toward an advertisement, therefore, influencing the consumer to purchase a product or not. Since young adults tend to be the most involved in celebrities' lives, this study examined how those characteristics influence those individuals to purchase a given product in an advertisement.

\section{Chapter 3: Hypotheses}

Based on the literature mentioned in the previous section, the study examined the three characteristics of trustworthiness, expertise and attractiveness of the endorser within a given advertisement and how Millennials' social media use influences their purchasing intentions. Using a survey method, Millennials' social media use was examined in relation to the three characteristics and a celebrity's influence on Millennial's purchasing intentions. Since Millennials reported on an endorsement in which a good pairing occurred, the match-up hypothesis was assumed and controlled for. A well-matched advertisement with a celebrity should feature a celebrity who "matches" the characteristics of the brand or the advertisement. For example, razors are used to enhance one's physical attractiveness, and therefore, the celebrity-based advertisement should feature someone who is also physically attractive (Kahle \& Homer, 1985). This type of razor advertisement may convey information about the quality and the benefits of the product to the consumer, and would therefore influence his or her purchase intention. Many studies look just at these three characteristics as a whole and how they influence overall consumer purchasing intentions. Gender has also been studied in relation to how males and females are influenced by the three characteristics. However, age categories 
and these three characteristics of celebrities in coordination with Millennials' social media use have not been looked at as closely.

In order to test the relationship between Millennials' social media use, effect on purchasing intention and the three characteristics, two separate hypotheses were developed:

$\mathrm{H} 1$ : Out of the three celebrity characteristics, attractiveness will have the strongest positive and significant association with Millennials' purchasing intentions.

H2: Amount of social media use among Millennials positively moderates the relationship between celebrity-based endorsement characteristics and Millennials’ purchasing intentions.

The study examined how Millennials' social media use influences their purchasing intentions after being exposed to a celebrity-based endorsements. As seen in the literature (Till \&Busler, 2000; Ohanian, 1990; Lynch \& Schuler, 1994) fit of the endorser to the right brand is also another variable that needed to be examined in this study in order to see its effect on the advertisement as well. The amount of social media use, the characteristics (physical attractiveness, expertise and trustworthiness) of the endorser and the age of the consumer are the variables that were examined. Taking those variables, this study observed the effect these elements have on the message of the advertisement and how the endorsement affected the purchasing intention of the Millennial consumer. 


\section{Chapter 4: Methodology}

\subsection{Survey}

According to Wimmer and Dominick (2014), survey research can be used to investigate problems in realistic settings at a reasonable cost and across a wide geographic area. In addition, respondents may come from a variety of different backgrounds and lifestyles, therefore resulting in different answers to the survey questions. Surveys are also effective because "newspaper reading, television viewing, radio listening and consumer behavior patterns can be examined where they happen" (Wimmer \& Dominick, 2014, p. 192). The data yielded from this study is important because celebrity-based endorsements are all around us, and the public needs to be aware of the tactics being used within these advertisements in general to understand how their purchasing intentions are being influenced. Millennials need to be particularly aware because of how much celebrities influence our lives. However, advertisers can also benefit from the information provided from this study because they can be aware of how the three characteristics and amount of social media use work together to affect Millennials and their purchasing intentions since Millennials are more involved with celebrities through social media. An Internet survey was conducted, since it tends to be the most cost-effective method of research. Using an Internet-based survey allows the author to distribute the survey widely, removes geographic boundaries and allows for remote distribution.

Distribution of the survey occurred via a convenience sampling method. The survey was distributed to multiple journalism and communication undergraduate 
communications classes in order to obtain responses directly from Millennials. A convenience sampling method is one in which "individuals who fit the criteria of a study are identified in any way possible" (Emerson, 2015, p. 2). Distributing to college students allowed for Millennials to be directly studied, and teachers offered extra credit for students who took the survey, which resulted in a higher response rate.

\subsection{Survey Measures}

This study had two independent variables and one dependent variable. The independent variables were the amount of Millennials' social media use and the celebrity characteristics of attractiveness, expertise and trustworthiness. The dependent variable in this study was the effect of those two independent variables on the purchasing intention of Millennials. In the beginning of the survey, respondents were prompted to respond to three questions in which they described a certain celebrity endorsement they saw on social media. He or she was asked what celebrity was in the endorsement, what product the celebrity was endorsing and what social media platform her or she saw the endorsement on. For the question asking what celebrity was in the endorsement, respondents' answer to this question was placed in the questions measuring source credibility, source attractiveness and their social media use in relation to that celebrity. Having the name be specific to the respondents' answer kept respondents focused on one specific celebrity throughout the entire survey process. In addition, respondents were also asked their interest in celebrity endorsers and celebrities in general with response options ranging from "not at all interested" to "very interested." If a respondent chose "not at all interested," he or she was then redirected to the end of the survey. Those who aren't 
interested in celebrities may not be able to report on a celebrity endorser or may not provide the information that this study is seeking because they have low interest in celebrities to start off with and may not be influenced by celebrity endorsements as a result.

\subsubsection{Source credibility and source attractiveness (expertise, trustworthiness}

and attractiveness). When looking at the three characteristics of trustworthiness, attractiveness and expertise, previous research by Ohanian (1990) broke these three characteristics into two separate models: the source credibility and source attractiveness model. In order to measure both of these models, source credibility - trustworthiness, expertise - and source attractiveness was measured using semantic differential scales with a seven-point range of options between bi-polar adjectives. Each characteristic was measured with four to six different bi-polar adjectives, and respondents reported on the celebrity that they described in the beginning of the survey.

The measurement scale used within this study is based on Ohanian's (1990) research, which outlines the two models - source credibility and source attractiveness model - in coordination with the three celebrity characteristics. To measure expertise, the adjectives "expert," "experienced," "qualified," "authoritative," "informative," "intelligent" and "skilled" were used. Trustworthiness was measured with the adjectives “dependable" "trustworthy," "reliable," "honest" and "sincere." Attractiveness was measured using adjectives such as "attractive," "beautiful," "sexy," "classy," "sophisticated," "charming" and "elegant." Likability, which is a component of the source attractiveness model (Ohanian, 1990), was also measured with bi-polar adjectives 
such as "nice," "virtuous," "friendly" and "pleasant." In addition to the semantic differential scales used to measure these three characteristics, the trustworthiness of the celebrity within the endorsement was measured using a seven-point Likert-scale ranging from "strongly disagree" to "strongly agree," with two statements: "I trust (what celebrity was featured in the endorsement)'s opinion" and "I trust the brands and products that (what celebrity was featured in the endorsement) endorses." It is again important to note that "(what the celebrity was featured in the endorsement)" stands for the text that the respondents' entered at the beginning of the survey when they were prompted to report on a recent celebrity endorsement that they saw on social media.

4.2.2 Millennials' social media use. Social media has been growing in popularity since its beginnings, with more and more users logging on to various platforms. Millennials are one group that is seen logging on to social media platforms, with $73 \%$ of wired American teens using some form of social media platform (Lenhart et al., 2010). Millennials are also checking their social media platforms at least once a day with many checking them multiple times a day. In order to measure Millennials' social media use, the survey first asked participants "What social media platform do you use most often;" their response to this question was filled in later on for two additional questions to make it more applicable to every participant who may or may not use one specific social media platform. Other questions included "On average, approximately how many hours do you spend on social media each day? "Approximately how many times a day do you check your social media accounts?" "Approximately how many followers do you have on (whatever social media platform they use most often)?" and "Approximately how many 
celebrities do you follow on (whatever social media platform they use most often)?" Participants filled in how many times they check their social media accounts a day, how many hours they spend on social media and how many followers they have on social media on their own instead of providing already set ranges.

In addition to these questions, the survey also included seven Likert-scale questions that had a seven-point scale ranging from "strongly disagree" to "strongly agree" that measured participants' social media use and their involvement with the celebrity's social media accounts that they reported on in the beginning of the survey. The seven Likert-scale questions were, "I follow (what celebrity was featured in the endorsement) on social media," "I interact with (what celebrity was featured in the endorsement)'s social media content," "I check (what celebrity was featured in the endorsement)'s social media accounts daily," "I check (what celebrity was featured in the endorsement)'s social media accounts weekly," "I check (what celebrity was featured in the endorsement) media accounts monthly" and "I pay attention to the products and brands that (what celebrity was featured in the endorsement) is endorsing." Also, a respondent's identification with the given celebrity was measured by the statement, "I feel as though I know (what celebrity was featured in the endorsement) was featured in the endorsement." If a Millennial is identifying with a celebrity he or she is reporting on, then they are wanting to be like the celebrity, as explained by Kelman (1958). Millennials may also have a parasocial relationship or a sense of intimacy with the given celebrity (Chia \& Yip Ling, 2004), and would therefore be more inclined to feel as though they know the celebrity they are reporting on. 
4.2.3 Purchase intention. Purchase intentions are "an individual's conscious plan to make an effort to purchase a brand" (Spears \& Singh, 2004). Based on the celebritybased endorsement, Millennials are going to be influenced to either purchase the product or to purchase products from the brand being endorsed or they are not going to be influenced at all. As found in previous research (Lafferty \& Goldsmith, 1999), a consumer is more likely to purchase a product when he or she feels positively toward and understands a given endorsement. The goal of celebrity endorsements is to get consumers to purchase the product or to purchase from the brand being endorsed, and as such, it is important to measure the purchase intentions of Millennials after seeing the given advertisement they are reporting on to see how they have been influenced by the endorsement in coordination with their social media use.

To measure the purchasing intentions of Millennials, the survey asked if the respondent did or did not buy the product that they reported on within the first three questions. In addition, seven Likert-scale questions with a choice of seven different responses from "strongly disagree" to "strongly agree" were used to measure Millennials" purchasing intentions. Ohanian's (1990) three statements of self-report validity measures were included and asked participants how likely they were to "inquire about the brand," "consider purchasing the brand" and "purchase the brand" after seeing the given advertisement that participants reported on originally. Furthermore, respondents were also asked how likely they were to buy the product "later at a store or online," "if it is reasonably priced or affordable," "if it appears to be of great value" and "if it looks like something that my group of friends and I might normally use," which relates to the 
previous literature that states Millennials make careful choices about their purchases so they aren't perceived negatively by their peers. Four additional questions were added based on Dobbs, Monroe and Grewal's (1991) willingness to buy indicators. The first two questions were in a Likert-scale format with seven scale options from "strongly disagree" to "strongly agree." Participants rated their level of agreement with two statements, "I am very likely to buy the product or from the brand being advertised by (what celebrity was featured in the endorsement)" and "If I were going to buy this product or from this brand, I would consider buying the product or from the brand at the price advertised." Two other questions in a Likert-scale format were included where participants were asked to rate how likely he or she was to do two statements and were given eight different rating options from "extremely likely" to "extremely unlikely." The two statements were "The probability I would consider buying the product or from the brand is..." and "My willingness to buy the product or buy from the brand is..." Previous research (Karbala, \& Wanderbori, 2012) has found that demographics are important in influencing consumers' purchase intentions, and therefore demographic questions were included at the end of the survey. These demographic questions included gender, age, class rank and racial background. Two additional questions appeared in the demographic section, asking for participants' name and email. These two questions were only included to make sure that the students who did take the survey for extra credit got the credit. Participants were aware of the purpose of these two questions prior to taking the survey and prior to answering the two questions. 


\subsection{Analysis Process}

The survey was launched on Qualtrics shortly after receiving approval from the university's institutional review board (IRB), and was open for over two weeks to allow for responses to accumulate. The survey was opened on Tuesday, February 7, 2017, and was closed Wednesday, February 22, 2017. IRB approval was received and the approval letter from the IRB can be found in Appendix A. Once the survey closed, the data collected from Qualtrics was downloaded to analyze in SPSS.

Prior to analyzing the data, all the data was cleaned and the incomplete cases were removed so as not to skew the results. A regression analysis was run on each of the celebrity characteristics (expertise, trustworthiness and attractiveness) and Millennials' purchasing intentions in order to access the relationship between each of the three celebrity characteristics and their effect on Millennials' purchasing intentions and to see which characteristic had the strongest positive and significant association with Millennials' purchasing intentions. Additionally, a regression analysis was conducted on Millennials' purchasing intentions and their social media use to see how Millennials' amount of social media use affects their purchasing intentions. See figure one for a complete list of hypotheses, research questions and associated statistical tests. 
Figure 1

Hypotheses and Associated Statistics Tests

\begin{tabular}{|l|c|}
\hline Hypotheses and Research Questions & Statistical Tests \\
\hline $\begin{array}{l}\text { H1: Out of the three celebrity } \\
\text { characteristics, attractiveness will have the } \\
\text { strongest positive and significant } \\
\text { association with Millennials' purchasing } \\
\text { intentions. }\end{array}$ & $\begin{array}{l}\text { Descriptive Statistic } \\
\text { Multiple Regression }\end{array}$ \\
\hline $\begin{array}{l}\text { H2: Amount of social media use among } \\
\text { Millennials positively moderates the } \\
\text { relationship between celebrity-based } \\
\text { endorsement characteristics and } \\
\text { Millennials' purchasing intentions. }\end{array}$ & $\begin{array}{l}\text { Descriptive Statistic } \\
\text { Multiple Regression }\end{array}$ \\
\hline
\end{tabular}

To begin the data analysis, descriptive analyses were used on the three variables of the celebrity characteristics, Millennials' purchasing intentions and their social media use. Frequencies were run to determine the number of participants per gender, age range, class rank and race/ethnicity. Descriptives were run for the three separate celebrity characteristics of trustworthiness, expertise and attractiveness, along with the measures for purchase intentions and social media use. Note that the question regarding "Selfish:Unselfish" had to be recoded to match the format of the other bi-polar adjective rating questions. Some of the questions assessed social media use, such as "On average, approximately how many hours do you spend on social media each day," "Approximately how many times a day do you check your social media accounts," "Approximately, how many followers do you have on Twitter," and "Approximately, how many celebrities do you follow on Twitter," were not included in the descriptive analysis because their ranges varied greatly and were going to be examined through frequency measures. The descriptive analysis allowed for the skew and kurtosis to be 
examined to make sure each measure was between 1 and -1 skewness and kurtosis. Means of each variable measure question were examined as well, to make sure participants' responses were close to the expected mean.

Following running the descriptives, reliabilities were run for each variable to examine the Cronbach's alphas for the overall measure and for each question within the measure. Looking at the separate scales for the key variables, the Cronbach's alphas should be above .70 (Morgan, Leech, Gloeckner \& Barrett, 2012, p.129). To assess whether the data from the variable scales form reliable scales, Cronbach's alphas were computed. The first measurement scale, based on Ohanian's (1990) research, measured source expertise, trustworthiness and attractiveness. For expertise, the alpha was .934 , which indicates that the items underneath expertise would form a scale that was internally consistent. Similarly, the alpha for the trustworthiness $(\alpha=.883)$ and attractiveness scale $(\alpha=.883)$ indicated internal consistency. Looking at the last two measures used to form two scales for Millennials' social media use and Millennials' purchasing intentions, alphas of .875 for social media use and .860 for purchase intention also indicated internal consistency. See Table 3 for the complete list of means, standard deviations and Cronbach's alphas for each key variable. With all scales being above the .70 alpha, new variables were created and descriptive statistics were run on each measure, and their descriptives were run again to test skewness, kurtosis and means of the computed variables. 
Table 3

Means, Standard Deviations and Reliability Coefficients for Purchasing Intention

\section{Score}

Millennials' Purchasing Intentions

\begin{tabular}{ccc} 
Mean & SD & $\alpha / r$ \\
\hline 4.01 & 1.05 & .860
\end{tabular}

Expertise

5.22

1.77

.934

Attractiveness

5.18

1.09

.895

Trustworthiness

4.74

1.20

.883

Millennials' Social Media Use

3.33

1.31

.875

Note. Scores are on a scale of 1 to 7 from "strongly disagree" to "strongly agree." $n=297$

\section{Chapter 5: Results}

The purpose of this study was two-fold. First, the author sought to understand which of the three characteristics of trustworthiness, expertise and attractiveness of an endorser would have the strongest effect on Millennial's purchasing intentions. Secondly, the author wanted to look at the potential moderating relationship between celebritybased endorsement characteristics and Millennials' purchasing intentions based on Millennials' social media use. This chapter focuses on the findings associated with the aforementioned hypotheses and questions.

Before launching the survey, a pretest was conducted to ensure the survey was being displayed properly. The full questionnaire was sent to a sample of 10 people, in which only eight chose to participate After reviewing responses, the survey was deemed ready to launch. Using the Qualtrics interface, the full instrument was distributed to 11 journalism and communications undergraduate courses. Each participant received extra 
credit as determined by his or her professor for participating in the online survey. At the end of the data-collection period, there was a total of 394 responses. From the 394 responses collected, 97 incomplete or irrelevant responses had to be removed, resulting in 297 useable responses. The data analysis proceeded with a sample of 297 individuals who indicated they had some level of interest in celebrities and were willing to report on their social media use.

Of the 297 participants who completed the questionnaire, $41.1 \%(n=122)$ were males and $58.9 \%(n=175)$ were females. Approximately $60 \%(n=179)$ of participants were between the ages of 18 and 20 , followed by the 21 to 23 age group $(36.4 \%, n=108)$. Respondents in the 24 to 26 age group made up $2.9 \%(n=9)$ of the total sample, and only $0.3 \%(n=1)$ respondents were over the age of 27 . In terms of class rank, $21.9 \%(n=65)$ indicated they were freshman, $26.3 \%(n=78)$ were sophomores, $28.3 \%(n=84)$ were juniors, $22.9 \%(n=68)$ were seniors and $0.7 \%(n=2)$ were graduate students. Among the 297 respondents, $86.9 \%(n=258)$ indicated they were White, followed by $8.8 \%(n=26)$ who identified themselves as Black or African American followed by $2.4 \%(n=7)$ who identified themselves as Asian. There was a small percentage $(1.0 \%, \mathrm{n}=3)$ of participants who identified as either Hispanic or Latino or Spanish origin, or Middle Eastern. See table one for a complete list of descriptive statistics for respondent's demographic information.

For finding out more information about Millennials' social media use, questions assessing their most-used social media platform, the number of followers they have, how many celebrities they follow and how much they are on social media were asked. The 
questions included in this area were as follows: (1) In order to find out more about participant's online habits, we will ask a couple of questions addressing social media use. What social media platform do you use most often, (2) On average, approximately how many hours do you spend on social media each day, (3) Approximately, how many times a day do you check your social media accounts, (4) Approximately, how many followers do you have on Twitter and (5) Approximately, how many celebrities do you follow on Twitter? Frequencies were run on all five questions to analyze Millennials' social media use. Of the 297 participants, $12.1 \%(n=36)$ use Facebook most often, $46.8 \%(n=139)$ use Instagram, 32.7\% $(\mathrm{n}=97)$ use Twitter and 3\% $(\mathrm{n}=9)$ use YouTube most often. 5.4\% of the sample ( $\mathrm{n}=16)$ chose "other," and self-reported other social media platforms that weren't listed. Of these participants, $0.3 \%(\mathrm{n}=1)$ reported using Pinterest, $0.3 \%(\mathrm{n}=1)$ reported using Tumblr, $0.7 \%(\mathrm{n}=2)$ use Reddit and $4 \%(\mathrm{n}=12)$ use Snapchat. The average participant spends about 3.5 hours on social media a day and checks social media accounts approximately 22 times a day on average. Respondents' also followed an average of 48 celebrities on their most-used social media account, with some participants following none and some participants following 1,000 celebrities. Similarly, the number of individuals who followed celebrities on their most-used social media platform ranged anywhere from 0 to 5,000 followers, but participants had an average of 877 followers. 
Table 1

Descriptive Statistics for Respondents Demographic Variables

\begin{tabular}{|c|c|c|}
\hline Key Categorical Variable & $\%$ & $\mathrm{~N}^{\mathrm{a}}$ \\
\hline Gender: Male & 41.1 & 122 \\
\hline Female & 58.9 & 175 \\
\hline Class Rank: Freshman & 21.9 & 65 \\
\hline Sophomore & 26.3 & 78 \\
\hline Junior & 28.3 & 84 \\
\hline Senior & 22.9 & 68 \\
\hline Graduate & 0.7 & 2 \\
\hline Race/Ethnicity: Asian/Pacific Islander & 2.4 & 7 \\
\hline Black or African American & 8.8 & 26 \\
\hline Hispanic/Latino & 1.0 & 3 \\
\hline Middle Eastern & 1.0 & 3 \\
\hline White/Caucasian & 86.9 & 258 \\
\hline Age: $18-20$ & 60.0 & 179 \\
\hline $21-23$ & 36.4 & 108 \\
\hline $24-26$ & 2.9 & 9 \\
\hline $27+$ & .3 & 1 \\
\hline
\end{tabular}

To explore the perceptions of source credibility and source attractiveness, respondents were asked to respond to a series of bi-polar adjectives while considering 
their choice of celebrity endorser and the specific endorsement they were in. In addition, to measure Millennials' purchase intentions and Millennials' social media use, respondents had to rate their level of agreement on a 7-point Likert scale with answer options ranging from "strongly disagree" to "strongly agree." The items mentioned were used to explore the dimensions of the key variables of this study. After checking the reliability of each scale, new variables were computed and descriptives were run to examine the mean, standards deviations, skewness and kurtosis of the five key variables. Referring to table two, the three key variables under source credibility and source attractiveness vary in their means, standard deviations, skewness (between $+/-0.8)$ and kurtosis, but the means of all three are approximately five on a 7-point scale between two bi-polar adjectives. Note that expertise ratings were slightly skewed. The other two key variables of Millennials' purchasing intentions and their social media use had a mean of 4.01 and 3.33 respectively. Skewness and kurtosis for these two scales were within acceptable range as well. 
Table 2

Means, Standard Deviations, Skewness, Kurtosis and Reliability for Key Variables

\section{Score}

Millennials' Purchasing Intentions

\begin{tabular}{ccccc} 
Mean & SD & Skewnes & Kurtosis & $\alpha$ \\
\hline 4.01 & 1.05 & -0.17 & -0.22 & .860
\end{tabular}
(Dep.)

Expertise (Indp.)

Attractiveness (Indp.)

Trustworthiness (Indp.)

Millennials' Social Media Use (Indp.)

$5.22-1.77-0.96$

5.18

1.09$$
-0.66
$$

1.66

.934

4.74

$-0.19-0.32$

.883

$\begin{array}{llll}3.33 & 1.31 & 0.27 & -0.94\end{array}$

Note. Scores are on a scale of 1 to 7 from "strongly disagree" to "strongly agree." $n=297$

To explore the H1, a multiple regression was conducted to determine which of the three celebrity characteristics - trustworthiness, expertise or attractiveness - had the strongest positive and significant relationship with the dependent variable (Millennials' purchasing intentions). The multiple regression included the three independent variables of expertise, trustworthiness and attractiveness. The means, standard deviations and intercorrelations can be found in table five. Upon further examination of the results from the multiple regression, it appeared the three tolerance levels for expertise, trustworthiness and attractiveness highlighted an issue of multicollinearity. Multicollinearity is described as high intercorrelations among some of the predicator variables (Leech, Barrett \& Morgan, 2014). Low tolerance is considered any tolerance values that are less than $\left(1-\mathrm{R}^{2}\right)$, which equals 0.64 in this case. All three characteristics had values lower than 0.64 with trustworthiness having 0.38 , expertise 0.41 and 
attractiveness having 0.46 . These results showed that the three celebrity-based characteristic variables were not being viewed by respondents as three separate measures. They were measuring much of the same information, and therefore, could be combined into one variable.

Table 5

Means, Standard Deviations, and Intercorrelations for Millennial's Purchasing Intentions and Predictor Variables $(n=297)$

\begin{tabular}{|l|l|l|l|l|l|l|}
\hline Variable & M & SD & 1 & 2 & 3 & 4 \\
\hline $\begin{array}{l}\text { Millennial's } \\
\text { Purchasing } \\
\text { Intentions }\end{array}$ & 4.01 & 1.06 & $1.00^{* *}$ & $.18^{* *}$ & $.53^{* *}$ & $.61^{* *}$ \\
\hline Predictor Variable & & & & & & \\
\hline 1. Expertise & 5.21 & 1.18 & - & $.67^{* *}$ & $.74^{* *}$ & $.28^{* *}$ \\
\hline 2. Attractiveness & 5.18 & 1.09 & & - & $.70^{* *}$ & $.18^{* *}$ \\
\hline $\begin{array}{l}\text { 3. } \\
\text { Trustworthiness }\end{array}$ & 4.74 & 1.20 & & & - & $.50^{* *}$ \\
\hline
\end{tabular}

$* * \mathrm{p}<.05 ; * * \mathrm{p}<.01$

Correlations were then run on the three variables in question of multicollinearity to see how they interacted with one another. Table two shows that all three pairs of variables were significantly correlated. Of the three, the strongest positive correlation was between expertise and trustworthiness, $\mathrm{r}(297)=.74, p<.01$. This means that celebrities who were rated as experts were also viewed as trustworthy. Trustworthiness was also positively correlated with attractiveness $(\mathrm{r}=.70)$, and expertise was also highly correlated with attractiveness $(r=.67)$. Since all three variables were highly correlated, the first hypothesis was not supported. H1 relied on previous research that separated the three characteristics (Silvera \& Austad, 2004; Till \& Bustler, 2004; O’Mahony \& Meeghan, 
1998; Ohanian, 1990) to examine how each separate variable affected Millennials' purchasing intentions.

Since the three celebrity-based characteristics couldn't be analyzed as three separate scales, a factor analysis was run on the measures of trustworthiness, expertise and attractiveness to see if the three scales could, instead, be combined to form one general scale. To assess whether the data from the variables in each scale form one reliable scale, Cronbach's alphas were computed. The alpha for the overall celebritybased characteristic scale was .95 , which indicates that the items for each characteristic would form a scale that was internally consistent. Since the alpha was within the acceptable range of -1 and 1 , the measures for the celebrity-based characteristics were combined to create one variable.

Descriptives were run on the new variable to examine the mean, standard deviations, skewness and kurtosis of the three key variables that had been combined into one scale. Means, standard deviations and skewness of eight key variables are shown in table four. The variable of celebrity characteristics showed a slight skew issue (-.83), but the mean, kurtosis and standard deviation were normally distributed. The mean was approximately five on a 7-point scale between two bi-polar adjectives with a standard deviation of 1.02. In order to examine the slight issue that may have been happening, a histogram was analyzed, and the histogram showed a slight left skew of the data due to nine outliers (see Figure 2). The frequency charts for the descriptives showed that $97 \%$ $(n=288)$ of the sample was under the normal distribution curve. Only $3 \%(n=9)$ were outliers and averaged a 2.9 or less on the 7 -point scale. To make sure the new variable 
met a normal distribution, those cases that were outliers were sorted out of the data.

Sorting out the data allowed for it not to be included in the analysis without the results being deleted. After sorting the data, descriptives were run again to ensure that a normal distribution was met. The new mean (5.12), standard deviation (.86), skewness (-.09) and kurtosis (-.45) all showed a normal distribution after removing the outliers.

\section{Table 4}

Means, Standard Deviations, Skewness and Kurtosis for Combined Celebrity

Characteristics

\begin{tabular}{|c|c|c|c|c|c|}
\hline & \multicolumn{4}{|c|}{ Score } & \multirow[b]{2}{*}{$\alpha$} \\
\hline & Mean & $\mathrm{SD}$ & Skewness & Kurtosis & \\
\hline $\begin{array}{l}\text { Celebrity Characteristics (expertise, } \\
\text { trustworthiness and attractiveness) }\end{array}$ & 5.01 & 1.02 & -.83 & 1.56 & .95 \\
\hline $\begin{array}{l}\text { Celebrity Characteristics - After } \\
\text { removal of outliners }\end{array}$ & 5.12 & .86 & -.091 & -.45 & .95 \\
\hline
\end{tabular}


Figure 2

Histogram for Celebrity Characteristics Combined

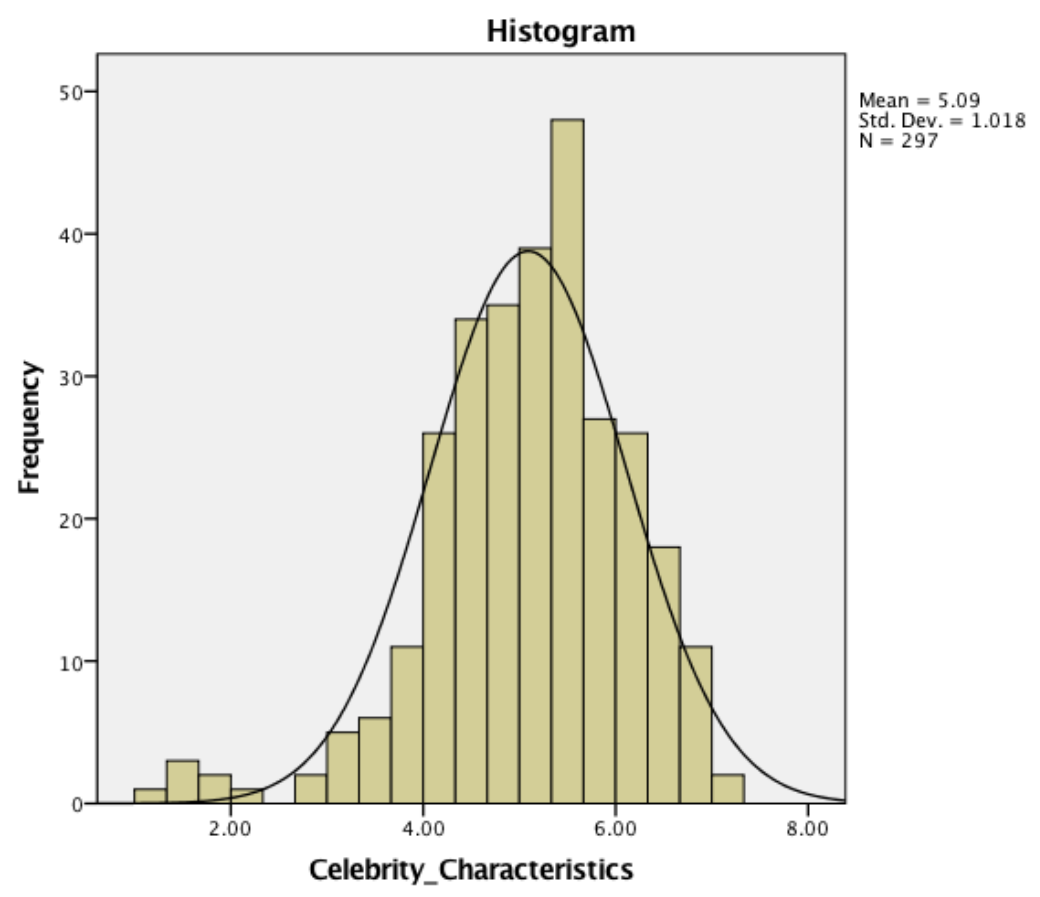

Since the variables for expertise, trustworthiness and attractiveness could no longer be analyzed as separate measures, H2 could not be analyzed as was originally hypothesized. $\mathrm{H} 2$ assumes that the amount of social media use among Millennials positively moderates the relationship between the celebrity-based endorsement characteristics and Millennials' purchasing intentions. Originally, the hypothesis caused for analyzing whether Millennials' social media use acts a moderator between the three separate celebrity-based characteristics and their resulting purchase intentions. Therefore, H2 was not supported based on this idea of having to combine the characteristics into one variable. However, a hierarchical regression was still run between the Millennials' social media use and the variable of celebrity characteristics. 
Based on table six, the hierarchical regression analysis looked at how well participants' social media use and the celebrity-based characteristics predicted participants' purchasing intentions after controlling for their social media use. Means and standard deviations are presented in table two and table three When participants' social media use was entered alone, it significantly predicted participants' purchasing intentions, $F(1,286)=158.93, \mathrm{p}=.001$, adjusted $\mathrm{R}^{2}=.36$. This $\mathrm{R}^{2}$ value means that $36 \%$ of the variance in participants' purchase intentions can be predicted by participants' social media use. When the other variable was added to the regression analysis, it significantly hurt the prediction, $\mathrm{R}^{2}$ change $=22.83, F(2,285)=96.94, \mathrm{p}<.001$, meaning the celebrity characteristics were no longer a factor. Participants' social media use alone significantly predicted participants' purchasing intentions, $F(1,286)=158.93, \mathrm{p}=.001$, adjusted $\mathrm{R}^{2}=.36$.

Table 6

Hierarchical Multiple Regression Analysis Summary Predicting Millennials' Social Media Use from the Celebrity Characteristics (Expertise, Attractiveness and Trustworthiness).

\begin{tabular}{|l|l|l|l|l|l|}
\hline Variable & $B$ & $S E B$ & $\beta$ & $R^{2}$ & $\Delta R^{2}$ \\
\hline Step 1 & & & & .36 & .36 \\
\hline $\begin{array}{l}\text { Millennials Social } \\
\text { Media Use }\end{array}$ & .49 & .04 & $.60^{* *}$ & & \\
\hline Constant & 2.41 & .14 & & .41 & .05 \\
\hline Step 2 & & & $.49^{* *}$ & & \\
\hline $\begin{array}{l}\text { Millennials Social } \\
\text { Media Use }\end{array}$ & .40 & .04 & $.24 * *$ & & \\
\hline $\begin{array}{l}\text { Celebrity } \\
\text { Characteristics }\end{array}$ & .30 & .62 & & & \\
\hline Constant & 1.16 & .29 & & & \\
\hline
\end{tabular}

$* \mathrm{p}<.05 ; * * \mathrm{p}<.001$ 
A hierarchical liner regression was also run using the standardized variables of participants' social media use, participants' purchasing intentions and the variable composed of the three celebrity-based characteristics. With standardized variables, the data is transformed to a standard score that has a mean of 0 and a standard deviation of 1 for each variable scale. $\mathrm{Z}$ scores for each data point of the three variables were computed, and the descriptives were run on the $\mathrm{z}$ scores. The descriptives for each still showed a normal distribution for each variable scale. The two scales for participants' purchasing intentions and celebrity characteristics were multiplied to create a new variable interaction - to see how participants' social media use interacted with the celebrity characteristics to affect overall purchasing intentions, much like what was done before. The results indicated the same $\mathrm{R}^{2}$ as reported in table six, and reinforced the notion that participants' social media use significantly predicts their purchasing intentions.

\section{Chapter 6: Discussion}

The purpose of this study was to investigate the relationship between the three celebrity-based endorsement characteristics - expertise, attractiveness and trustworthiness - and Millennials' purchasing intentions when taking into consideration their social media usage. To explore these questions, the study first investigated which celebrity-based characteristic had the most positive, significant effect on Millennials' purchasing intentions. Then, Millennials' social media use was examined to see if social media use mediated the relationship between the celebrity-based endorsement characteristics and Millennials' purchasing intentions. This chapter first discusses implications from the results that may provide some insight for brands and organizations. 
The author then reviews limitations of the study. Finally, the author concludes with the main findings of this study and puts forward suggestions for further research.

\subsection{Findings and Implications}

Though the results for both hypotheses for this study were not supported due to the celebrity-based endorsement characteristics not being viewed as three separate characteristics by the participants, the results still have an impact on the overall research of celebrity-based endorsements. One of the most notable contributions to the overall field is that the three characteristics (expertise, attractiveness and trustworthiness) are not viewed as they have been in previous research (O’Mahoney \& Meenghan, 1998; Ohanian, 1990; Pornpitakpan, 2004; Chaiken, 1979). This previous research did not report on their tolerance levels or correlations within the research, but their results indicated the scales were reliable. In addition, they had been separated into three characteristics to form the source credibility model, which expertise and trustworthiness fall under, and the source attractiveness model (Ohanian, 1990). However, the present study indicated through a regression analysis for $\mathrm{H} 1$ that all three variables of expertise, attractiveness and trustworthiness were significantly correlated. The results also indicated the three variables' tolerance levels for expertise, trustworthiness and attractiveness where all lower than $0.64\left(1-\mathrm{R}^{2}\right)$ - trustworthiness was at 0.38 , expertise 0.41 and attractiveness 0.46 . Results for this study show that all three characteristics were highly correlated and were therefore being viewed as dependent on each other through the eyes

of Millennials. The reason this may have occurred can be attributed to the halo effect and the cognitive consistency theory. 
The halo effect was originally coined by Thorndike (1920) after he made the connection following his study looking at how supervisors rate their subordinates. His results showed that supervisors seemed unable to rate their subordinates independently on different characteristics (Thorndike, 1920; Leuthesser, Kohli \& Harich, 1995). But, according to Nisbett and Wilson (1977), the halo effect it is now described as "the influence of a global evaluation on evaluations of individual attributes of a person," ( $p$. 250). Simply put, if we like a person, or in the case of this study a celebrity, we often assume that people we perceive as nice or attractive have all favorable attributes, and those we perceive as less nice have less-favorable attributes. In addition, the cognitive consistency theory ties in with the halo effect. The theory states that people are more comfortable when all their judgments about a person or product go together or are all positive or negative (Erogan, 1999). For respondents in this study, the survey began by asking questions related to a recent celebrity endorsement they had seen on social media (see Appendix C). Respondents had to report who the celebrity endorser was, the product that was being endorsed and the platform that it was seen on. According to the halo effect and cognitive consistency theory, if participants viewed the celebrity as positive, then all their responses addressing the celebrity-based endorsement characteristics were also positive. If they viewed the celebrity as negative, all their responses were then more negatively based for each of the characteristics.

Heuristics surrounding individuals' perceptions of celebrities could also affect how Millennials view the characteristics. According to Frizzell (2011), celebrities may act as a heuristic for individuals by reducing the amount of information necessary for 
them to form an opinion. Celebrities can cue individuals in on what issues they should care about and can influence what products consumers should be buying and what brands they should be buying from. Using this idea of a heuristic, Frizzell (2011) bases the idea on political candidates, saying, "Whether a respondent is considered respected, and thus used as a heuristic, is a function of the perceived knowledge of the speaker: when citizens view the source of information as being knowledgeable about a subject they are more likely to accept the information than they would be otherwise," (p. 315). Therefore, applying both this idea, the halo effect and the cognitive consistency theory, if a Millennial views a celebrity as positive then he or she is more likely to accept or be persuaded by the celebrity based-endorsement.

As the results show, the mean for the combined variable for the celebrity characteristic was 5.01, showing that most respondents viewed the given celebrity as more positive. This finding of how Millennials view the three characteristics as one item and not three separate items is significant because it breaks the norm of past research. This finding is important for future brands and corporations that are targeting Millennials with the end goal of a purchase. Online celebrity endorsements are often more expensive, and rates can go as high as Kim Kardashian's payment of $\$ 10,000$ for a Twitter endorsement (Piazza, 2012). Therefore, brands and corporations need to know how these characteristics are viewed by Millennials to make the best match possible for an endorsement.

Finally, results from this study also influence our knowledge regarding how Millennials' social media use affects their purchasing intentions after seeing an 
endorsement on social media. The descriptives reported on in the results chapter note that the average respondent spends 3.5 hours a day on social media and during that time checks his or her social media accounts approximately 22 times a day. Furthermore, past research supports the idea that Millennials are active on social media, and $93 \%$ of 12 - to 17-year-olds and young adults (18- to 29-year-olds) are online (Lenhart et alt., 2010). As such, the results of the survey indicated that participants' social media use had an impact on participants' purchasing intentions after seeing a celebrity-based endorsement. The higher one's social media use, the more likely he or she is to buy the product being endorsed by the celebrity.

Millennials are on social media and are interacting through retweeting, liking and commenting on celebrity's content, some of which may be endorsements. Their interaction with celebrities is causing a parasocial interaction to form, making the Millennial want to be more like that given celebrity. Hence, this relationship makes Millennials trust the given celebrity and, therefore, their opinions. If a Millennial views a given celebrity positively, trusts his or her opinion and feels a relationship is there, the Millennial will want to buy the product that the celebrity is endorsing. In addition, Millennials may also just be more trusting of social media and the information that comes from it. Akar and Topcu (2011) found that undergraduate college students within the Millennial age range who are frequent users of social media have more positive attitudes toward social media marketing. News, endorsements and just general information can be obtained from social media, and Millennials trust the medium through which it comes, and therefore the messages that are communicated. 
While neither hypothesis was supported, the results of this study still highlight important aspects and findings that will affect future research in this area as well as provide organizations and brands additional knowledge when faced with the task of picking an endorser. Endorsements do cost brands money, but if the endorsement can influence purchase intentions of consumers, then the money has been well spent. Therefore, companies need to make sure they are using the right tactics, knowledge and research to ensure they are making the best decision for their endorsement.

\subsection{Limitations}

Like any other study, this effort had limitations. One of the primary limitations that existed is the sample may be underrepresenting the entire population due to respondents not answering the questions in the proper manner. Respondents could answer how they wish and they may have been tempted to pick the answer that they think is "correct." Respondents, who got extra credit for taking part in the survey, may have also not taken the survey seriously because they were just rushing through the questions to get the credit and not actually thinking about them. In addition, many respondents started the survey but never finished it, which resulted in the exclusion of those respondents from the survey and a lower response rate. Wimmer and Dominick (2014) commented on the topic of a low response rate saying that survey research is difficult to conduct due to the possibility of a low response rate. Participants were recruited within classrooms for participation in the study, and they had the choice to take it or not. Many potential respondents may have forgotten to take the survey, or may have thought they missed the 
deadline to take it, and therefore their responses were not included in the analysis. Individuals in that situation may offered more insight into the topic.

Another limitation that existed is regarding the sample. First and foremost, the sample was of only West Virginia University students, and not of other Millennials in the nation. The sample may have not represented all Millennials because Millennials may have different ideas, thoughts and opinions in other areas. West Virginia students are only a subset of the Millennial population, and therefore the participants being only from this university may not be representative of all Millennials. In addition, the sample collected was $86.9 \%(\mathrm{n}=258)$ white, and this may add to the misrepresentation of all Millennials. A more diverse sample might have revealed different perspectives, as individuals of different ethnicities may respond and think differently of celebrity endorsements.

The sample also was of only one age segment of the population as well, and Millennials only represent 21 to $26 \%$ of the population, according to McCormick (2016). With 93\% of this age group being online (Lenhart, Purcell, Smith \& Zickuhr, 2010), they may be more likely to interact with celebrities on social media daily, and therefore, are more likely to be convinced that the social media platform they are using provides truthful information. According to the Pew Research Center, 79\% of 30- to 49-year-olds, $61 \%$ of 50 - to 64 -year-olds and $36 \%$ of individuals 65 and older use a form of social media ("Social Media Fact Sheet," 2017). Individuals outside of Generation Y might provide different results as their social media use is lower than that of Generation Y, and they may have the experience to more carefully assess celebrity based endorsements. As 
older users of social media, their purposes for using social media may not revolve around interacting with celebrities and trying to be like them. The generations that came before Generation Y would provide a comparative landscape to how social media use and the three celebrity characteristics influence purchasing intentions of different age demographics.

The length of the survey may also have been a limitation because with 24 questions, respondents may have lost patience and quit before completion of the survey, which would have caused a lower response rate. Just based on the amount of incomplete responses, (94), this may have been a contributing factor. In addition to the twenty-four questions, there were also big blocks of questions as well that may have tired participants during the survey. At the end of data collection, the author had 394 responses, but there were only 297 complete ones, resulting in a completion rate of $75 \%$.

\subsection{Future Research}

Findings from this study, however, provide a foundation for future research. Within the topic of celebrity-based endorsements and the age demographic of Millennials, this study provides a template for future research that aims to look at celebrity-based endorsements across various age demographics. Repeating this study across multiple generations may shed light on how other age groups' purchasing intentions are affected by celebrity-based endorsements, and how their social media use plays into that relationship. In addition, replicating a similar study for a wider age demographic could also reveal that different age groups are affected differently by celebrities and/or that they hold the three celebrity characteristics differently in 
importance for purchasing a product. For example, those 65 and older may be more affected by a celebrity endorsement that features a celebrity they feel is an expert, as opposed to 30- to 49-year-olds whose purchase intentions may be affected by an attractive celebrity. Building on this idea, seeing how males and females compare in this setting would be interesting as well.

Additional research should also look at different social media platforms in relation to this study. Perhaps one social media platform is more effective at influencing Millennials' purchasing intentions and another negatively affects it. With various platforms that are out there and available, it would be interesting to examine this idea deeper to help companies and brands choose which social media platform would be the most effective. Furthermore, it may also depend on the brand or product being endorsed. Perhaps, clothing products do better on Instagram and athletic product endorsements influence purchasing intentions more effectively on Twitter. Separating and analyzing how various social media platforms compare in terms of this study would be beneficial to the topic of celebrity based-endorsements as a whole by providing research for companies and brands to base their social media promotional efforts around to have an effective endorsement.

Future research could also focus on different celebrities combined with various products, and how the varying combinations of the celebrity-based characteristics affect purchasing intentions of Millennials specifically or various age demographics. Perhaps athletes are more effective as celebrity endorsers depending on individuals' involvement with various sports. Another aspect to focus on is the specific social media platform that 
the endorsement was seen on. Social media platforms have their strengths and weaknesses, and celebrities can also vary in their presence across platforms as well. It would be interesting to make comparisons on how the celebrity-based characteristics are portrayed across each platform and which ones seem to be the most effective.

Building on the previous idea, future research could also look more in-depth at different varieties or categories of celebrities, such as athletes, actors or actresses, social media stars and so on. Doing a study looking more specifically at these different celebrity types would expand the present study by testing the match-up hypothesis while also potentially causing there to be more diversity in the ratings of the three characteristics. Having respondents report on the most recent endorsement they saw, or providing photos for them to examine would be two different ways to set up the study to examine the match-up hypothesis. According to Till and Busler (2000), the match-up hypothesis states that endorsers are more effective when there is a fit between endorser and the endorsed product. The present study assumed the match-up hypothesis by having respondents report on a celebrity endorsement of their choosing. As such, respondents may have felt that the endorsement was effective because they chose to report on it and viewed the celebrity more favorably already. Not allowing the respondent to have the freedom to choose which celebrity endorsement they report on allows there to be both effective and ineffective endorsements in terms of the match-up hypothesis. Assuming the match-up hypothesis for the study may have limited the study as well by setting respondents up to respond more positively to the characteristics. Respondents may have felt more positively about the endorsement and the celebrity overall because they may already find that 
celebrity favorable through following them on social media. Through following the given celebrity on social media, the respondent probably saw the given endorsement and found it more favorable because of having that parasocial interaction with the celebrity. Conducting a study that looks at the various celebrity types would be able to address the match-up hypothesis more effectively and may provide researchers with more variance in the characteristic ratings.

Another approach that could be taken is looking at how the results from this study would differ during and after a celebrity endorser experienced a public relations crisis. Depending on what the crisis is, Millennials' feelings toward the given celebrity may be affected, potentially causing them to lose interest in the celebrity for a short time or for good. When a Millennial's feelings towards a celebrity are being negatively affected, he or she may be less likely to want to believe the celebrity endorsements or purchase the brands or products he or she is endorsing. Given time, their feelings may change, but it would be interesting, nevertheless, to see how Millennials would respond to this study when the celebrity they report on, or the celebrity they are given, has gone through or is going through a public relations crisis. Doing a study along these lines would help to bring celebrity endorsement research full circle by providing companies with the information needed to combat the potential side effects of a celebrity endorser who is experiencing a public relations crisis.

Additionally, our understanding of the effectiveness of celebrity-based endorsements, the three celebrity characteristics, Millennials' social media use and their resulting purchasing intentions would be enhanced by employing other methodologies to 
investigate the relationship among the independent variables used in this study. For example, qualitative research methods, such as focus groups and in-depth interviews, may provide a more thorough understanding of other variables that point to attitudes, motivations to purchase and perceptions. Experiments with varying combinations of celebrity endorsements and brands or products could provide a more complete understanding of the relationship among the variables. Ethnographic research looking at Millennials' or other consumers' actual purchase behaviors and social media use could also add to our understanding of the relationship between the variables.

\section{Chapter 7: Conclusion}

Employing a web-based survey $(\mathrm{n}=297)$, this study explored the relationship among the three celebrity-based characteristics (trustworthiness, attractiveness and expertise), Millennials' social media use and Millennials' resulting purchasing intentions. Findings from the survey showed that contrary to previous research, Millennials view the three celebrity-based characteristics as one measure instead of three separate measures. Those findings also indicated that Millennials may be affected by the halo effect, heuristics and the cognitive consistency theory, which work together to state that when individuals think one way about a celebrity (positive or negatively), individuals feel the rest of their characteristics follow their original perceptions about the celebrity. Individuals also feel they need to keep all their perceptions together based on the cognitive consistency theory. Unfortunately, due to this result, neither hypothesis could be tested. Therefore, neither was supported, since the differences between the characteristics couldn't be assessed. 
However, the findings stand to highlight that original perceptions of how expertise, attractiveness and trustworthiness are not being viewed the same by Millennials. Perhaps, different generations view the three characteristics differently, and future research could explore this idea. Though the three characteristics being combined into one variable did not support either hypothesis, a regression analysis was run between the computed variable of all the characteristic combined and Millennials' overall social media use to see which still had the most significant effect on Millennials' purchasing intentions. Of the two, Millennials' social media use had a more significant effect on participants' purchasing intentions, indicating that the more that Millennials' are online and interacting with endorsement content from celebrities that they follow, the more likely they are to purchase the brand or product being endorsed. 


\section{References}

Ajzen, I. (1985). From intentions to actions: A theory of planned behavior. In J. Kuhl \& J. Beckman (Eds.), Action-control: From cognition to behavior (pp. 11-39). Heidelberg, Germany: Springer. doi:10.1007/978-3-642-69746-3_2

Akar, E. and Topcu B. (2011), “An Examination of the Factors Influencing Consumers' Attitudes toward Social Media Marketing”, Journal of Internet Commerce 10: 1035.

Alsmadi, S. (2006). The Power of Celebrity Endorsement in Brand Choice Behavior: An Empirical Study of Consumer Attitudes. Journal of Accounting, Business \& Management, 1369-84.

Badenhausen, K. (2016, December 27). The 10 Most Marketable Athletes Of 2016. Retrieved April 04, 2017, from https://www.forbes.com/sites/kurtbadenhausen/2016/12/27/the-10-most$\underline{\text { marketable-athletes-of-2016/ - 19ca16814fe7 }}$

Baker, M. J., \& Churchill Jr., G. A. (1977). The Impact of Physically Attractive Models on Advertising Evaluations. Journal of Marketing Research (JMR), 14(4), 538555.

Baltar, F., \& Brunet, I. (2012). Social research 2.0: virtual snowball sampling method using Facebook. internet Research, 22(1), 57-74.

Belch, G. E., \& Belch, M. A. (2013). A content analysis study of the use of celebrity endorsers in magazine advertising. International Journal Of Advertising, 32(3), 369-389. doi:10.2501/IJa-32-3-369-389 
Bergman, S. M., Fearrington, M. E., Davenport, S. W., \& Bergman, J. Z. (2011).

Millennials, narcissism, and social networking: What narcissists do on social networking sites and why. Personality and Individual Differences, 50(5), 706-711.

Botterill, J., Bredin, M., \& Dun, T. (2015). Millennials' Media Use: It Is a Matter of Time. Canadian Journal of Communication, 40(3), 537-551.

Brown, W. J., \& Basil, M. D. (1995). Media celebrities and public health: Responses to 'Magic' Johnson's HIV disclosure and its impact on AIDS risk and high-risk behaviors. Health Communication, 7(4), 345-370.

Boon, S. D., \& Lomore, C. D. (2001). Admirer-celebrity relationships among young adults. Human Communication Research, 27(3), 432-465.

Cacioppo, J. T., \& Petty, R. E. (1979). Effects of message repetition and position on cognitive response, recall, and persuasion. Journal of personality and Social Psychology, 37(1), 97.

Casey, M. K., Allen, M., Emmers-Sommer, T., Sahlstein, E., Degooyer, D. A. N., Winters, A. M. \& Dun, T. I. M. (2003). When a celebrity contracts a disease: The example of Earvin" Magic" Johnson's announcement that he was HIV positive. Journal of Health Communication, 8(3), 249-265.

Chaiken, S. (1979). Communicator physical attractiveness and persuasion. Journal of Personality And Social Psychology, 37(8), 1387-1397. doi:10.1037/00223514.37.8.1387

Chan, K., Ng, Y. \& Luk, E. (2013). Impact of celebrity endorsement in advertising on brand image among Chinese adolescents. Young Consumers 14.2: 167-179. 
Chia, S. C., \& Yip Ling, P. (2009). Media, Celebrities, and Fans: An Examination of Adolescents' Media Usage and Involvement with Entertainment Celebrities. Journalism \& Mass Communication Quarterly, 86(1), 23-44.

Cook, C., Heath, F., \& Thompson, R. L. (2000). A meta-analysis of response rates in web-or internet-based surveys. Educational and psychological measurement, 60(6), 821-836.

Costanzo, P. J., \& Goodnight, J. E. (2006). Celebrity endorsements: Matching celebrity and endorsed brand in magazine advertisements. Journal of Promotion Management, 11(4), 49-62

Daneshvary, R., \& Schwer, R. K. (2000). The association endorsement and consumers' intention to purchase. Journal of consumer marketing, 17(3), 203-213.

Dean, D. H. (1999). Brand endorsement, popularity, and event sponsorship as advertising cues affecting consumer pre-purchase attitudes. Journal of Advertising, 28(3), 112.

Dodds, W. B., Monroe, K. B., \& Grewal, D. (1991). Effects of price, brand, and store information on buyers' product evaluations. Journal of Marketing Research, 307319.

Emerson, R. W. (2015). Convenience Sampling, Random Sampling, and Snowball Sampling: How Does Sampling Affect the Validity of Research?. Journal of Visual Impairment \& Blindness, 109(2), 164-168.

Erdogan, B. Z. (1999). Celebrity Endorsement: A Literature Review. Journal of Marketing Management,15(4), 291-314. 
Fleck, N., Korchia, M., \& Le Roy, I. (2012). Celebrities in advertising: looking for congruence or likability?. Psychology \& Marketing, 29(9), 651-662.

Fraser, B. P., \& Brown, W. J. (2002). Media, Celebrities, and Social Influence: Identification with Elvis Presley. Mass Communication \& Society, 5(2), 183-206.

Frizzell, C. (2011). Public opinion and foreign policy: The effects of celebrity endorsements. The social science journal, 48(2), 314-323.

Gardner, M. P., \& Shuman, P. J. (1987). Sponsorship: An Important Component of the Promotions Mix. Journal Of Advertising, 16(1), 11-17.

Georgiadis, M. (2013). Motivating Behavior Change: A Content Analysis of Public Service Announcements from the" Let's Move!" Campaign. Elon Journal of Undergraduate Research in Communications, 4(1), 10-13.

How can we help? (n.d.). Retrieved April 04, 2017, from http://www.qscores.com/default.aspx

Hung, K., Chan, K. W., \& Caleb, H. T. (2011). Assessing celebrity endorsement effects in China. Journal of Advertising Research, 51(4), 608-623.

Kahle, L. R., \& Homer, P. M. (1985). Physical Attractiveness of the Celebrity Endorser: A Social Adaptation Perspective. Journal of Consumer Research, 11(4), 954-961.

Kahle, K. E., \& Kahle, L. R. (2006). Sports celebrities' image: a critical evaluation of the utility of Q scores. Creating Images and the Psychology of Marketing Communication, 191. 
Kamins, M. A. (1990). An Investigation into the "Match-Up" Hypothesis in Celebrity Advertising: When Beauty May be Only Skin Deep. Journal of Advertising, 19(1), 4-13.

Karbala, A., Wandebori, H. (2012). Analyzing the factors that affect consumer's purchase intention in Toimoi Store, Indonesia. Proceedings from 2nd International Conference Business, Economics, Management and Behavioral Sciences. Bali, Indonesia.

Kanungo, R. N., \& Pang, S. (1973). Effects of human models on perceived product quality. Journal of Applied Psychology, 57(2), 172-178. doi:10.1037/h0037042

Kaplowitz, M. D., Hadlock, T. D., \& Levine, R. (2004). A comparison of web and mail survey response rates. Public opinion quarterly, 68(1), 94-101.

Kelman, H. (1958). Compliance, identification, and internalization: Three processes of attitude change. Journal of Conflict Resolution, 2, 51-60

Lafferty, B. A., \& Goldsmith, R. E. (1999). Corporate credibility’s role in consumers' attitudes and purchase intentions when a high versus a low credibility endorser is used in the ad. Journal of Business Research, 44(2), 109-116.

Leech, N. L., Barrett, K. C., \& Morgan, G. A. (2014). IBM SPSS for intermediate statistics: Use and interpretation. Routledge.

Lenhart, A., Purcell, K., Smith, A., \& Zickuhr, K. (2010). Social Media \& Mobile Internet Use among Teens and Young Adults. Millennials. Pew internet \& American life project. 
Lenhart, A., Madden, M., Smith, A., Purcell, K., Zickuhr, K., \& Rainie, L. (2011). Teens, Kindness and Cruelty on Social Network Sites: How American Teens Navigate the New World of. Pew Internet \& American Life Project.

Leuthesser, L., Kohli, C. S., \& Harich, K. R. (1995). Brand equity: the halo effect measure. European Journal of Marketing, 29(4), 57-66.

Levy, Mark (1979). Watching Television News as Parasocial Interaction,” Journal of Broadcasting, 23. 69-80.

Lynch, J., \& Schuler, D. (1994). The Matchup Effect of Spokesperson and Product Congruency: A Schema Theory Interpretation. Psychology \& Marketing, 11(5), 417-445.

Manning, M. (2009). The effects of subjective norms on behavior in the theory of planned behavior: A meta-analysis. British Journal of Social Psychology, 48(4), 649-705. doi:10.1348/014466608X393136.

Martin, James H. (1996), “Is the Athlete's Sport Important when Picking an Athlete to Endorse a Nonsupport Product?” Journal of Consumer Marketing, 13 (6), 28-43. McCracken, G. (1989). Who is the Celebrity Endorser? Cultural Foundations of the Endorsement Process. Journal of Consumer Research, 16(3), 310-321. Retrieved from http://www.jstor.org/stable/2489512

McCormick, K. (2016). Celebrity Endorsements: Influence of a product-endorser match on Millennials attitudes and purchase intentions. Journal of Retailing and Consumer Services, 32, 39-45. 
Miller, G. R., \& Baseheart, J. (1969). Source Trustworthiness, Opinionated Statements, and Responses to Persuasive Communication. Speech Monographs, 36(1), 1.

Money, R. B., Shimp, T. A., \& Sakano, T. (2006). Celebrity endorsements in Japan and the United States: Is negative information all that harmful? Journal of Advertising Research, 46(1), 113-123.

Morgan, G. A., Leech, N. L., Gloeckner, G. W., \& Barrett, K. C. (2012). IBM SPSS for introductory statistics: Use and interpretation. Routledge.

Nisbett, R. E., \& Wilson, T. D. (1977). The halo effect: Evidence for unconscious alteration of judgments. Journal of personality and social psychology, 35(4), 250.

Nulty, D. D. (2008). The adequacy of response rates to online and paper surveys: what can be done?. Assessment \& Evaluation In Higher Education, 33(3), 301-314. doi:10.1080/02602930701293231

Ohanian, R. (1990). Construction and Validation of a Scale to Measure Celebrity Endorsers' Perceived Expertise, Trustworthiness, and Attractiveness. Journal of Advertising, 19(3), 39-52.

O'Mahony, S., \& Meenaghan, T. (1998). The impact of celebrity endorsements on consumers. Irish Marketing Review, 10(2), 15-24. Retrieved from

http://search.proquest.com/docview/204576526?accountid $=2837$

Patra, S., \& Datta, S. K. (2012). Celebrity Selection \& Role of Celebrities in creating Brand Awareness and Brand Preference - A Literature Review. Journal Of Marketing \& Communication, 8(2), 48-57. 
Pieters, R., Rosbergen, E., \& Wedel, M. (1999). Visual attention to repeated print advertising: A test of scanpath theory. Journal of Marketing Research, 424-438.

Piazza, J. (2012, January 28). How much can a celebrity make for tweeting? Retrieved from http://www.vulture.com/2012/01/how-much-can-a-celebrity-make-fortweeting.html?mid=nymag press

Pornpitakpan, C. (2004). The persuasiveness of source credibility: A critical review of five decades' evidence. Journal of Applied Social Psychology, 34(2), 243-281. doi:10.1111/j.1559-1816. 2004.tb02547.x

Pradhan, D., Duraipandian, I., \& Sethi, D. (2016). Celebrity endorsement: How celebrity-brand-user personality congruence affects brand attitude and purchase intention. Journal of Marketing Communications, 22(5), 456-473.

Schlecht, C. (2003). Celebrities' impact on branding. Center on Global Brand Leadership: Columbia Business School.

Shanklin, W. L., \& Miciak, A. R. (1997). Selecting sports personalities as celebrity endorsers. Journal of Promotion Management, 4(1), 1-11.

Shimp, T. A. (2003). Advertising, promotion, and supplemental aspects of integrated marketing communication. Mason, $\mathrm{OH}$ : South-Western.

Silvera D.H., \& Austad, B. (2004),"Factors predicting the effectiveness of celebrity endorsement advertisements", European Journal of Marketing, Vol. 38 Iss 11/12 pp. $1509-1526$

"Social Media Fact Sheet." (2017 January 12). Pew Research Center: Internet, Science \& Tech. Retrieved from http://www.pewinternet.org/fact-sheet/social-media/ 
Solomon, M. R. (2014). Consumer behavior: Buying, having, and being (Vol. 10). Engelwood Cliffs, NJ: Prentice Hall.

Solomon, M., Bamossy, G., Askegaard, S., \& Hogg, M. (1999). Consumer behaviour: a European perspective. New Yersey, ZDA: Prentice Hall Inc.

Spears, N., \& Singh, S. N. (2004). Measuring Attitude Toward the Brand and Purchase Intentions. Journal of Current Issues \& Research In Advertising (CTC Press), 26(2), 53-66.

Spry, A., Pappu, R. \& Cornwell, T.B. (2011) "Celebrity endorsement, brand credibility and brand equity", European Journal of Marketing, Vol. 45 Iss: 6, pp.882 - 909

Thomas, V. L., \& Fowler, K. (2015). More Isn't Always Better: Exploring the Influence of Familiarity When Using Multiple Celebrity Endorsers. Journal of Promotion Management, 21(2), 208-223. doi:10.1080/10496491.2014.996798

Thorndike, E. L. (1920). A constant error in psychological ratings. Journal of applied psychology, 4(1), 25-29.

Till, B.D. (1998),"Using celebrity endorsers effectively: lessons from associative learning", Journal of Product \& Brand Management, Vol. 7 Iss 5 pp. 400 - 409

Till, B. D., \& Busler, M. (1998),"Matching products with endorsers: attractiveness versus expertise", Journal of Consumer Marketing, Vol. 15 Iss 6 pp. 576 - 586

Till, B. D., \& Busler, M. (2000). The Match-Up Hypothesis: Physical Attractiveness, Expertise, and the Role of Fit on Brand Attitude, Purchase Intent and Brand Beliefs. Journal of Advertising, 29(3), 1-13. 
Tripp, C., Jensen, T. D., \& Carlson, L. (1994). The effects of multiple product endorsements by celebrities on consumers' attitudes and intentions. Journal of Consumer Research, 20(4), 535-547.

Wallenstein, A. (2016, June 21). Q Scores Stats Reveal Who's More Popular: Digital Stars vs. Mainstream Celebs. Retrieved April 04, 2017, from http://variety.com/2016/digital/news/youtube-stars-traditional-celebrities-data$\underline{1201799487 /}$

Wang, J. S., Cheng, Y. F., \& Chu, Y. L. (2013). Effect of celebrity endorsements on consumer purchase intentions: advertising effect and advertising appeal as mediators. Human Factors and Ergonomics in Manufacturing \& Service Industries, 23(5), 357-367.

Wimmer, R.D. \& Dominick J.R. (2014). Mass Media Research: An Introduction, (10th edition), Boston, MA: Wadsworth Publishing.

Wojcicki, J. M., \& Heyman, M. B. (2010). Let's move—childhood obesity prevention from pregnancy and infancy onward. New England Journal of Medicine, 362(16), 1457-1459. 
Appendix A- IRB Approval Letter

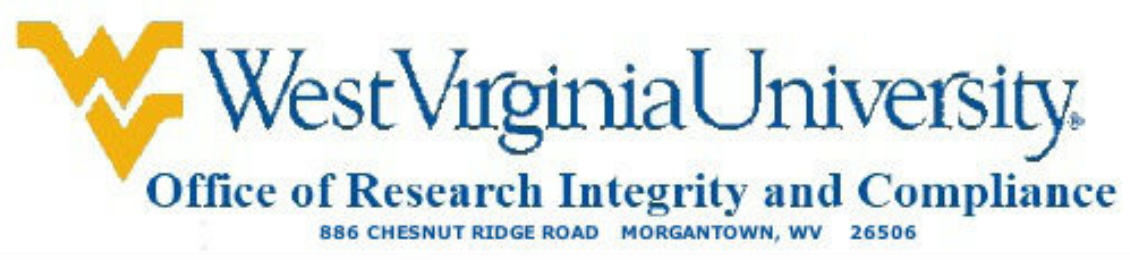

Acknowledgement Letter Exempt Initial Protocol Review

Action Date

To

From

Approval Date

Expiration Date

Subject

Protocol Number

Title

of Millennials
$01 / 31 / 2017$

Stephen Urbanski

WVU Office of Research Integrity and Compliance

$01 / 31 / 2017$

$01 / 30 / 2020$

Acknowledgement Letter Exempt Initial Protocol Review

1610324997

Celebrities Endorsers and Their Effect on Purchasing Intentions

The above-referenced study was reviewed by the West Virginia University Institutional Review Board IRB and was granted exemption in accordance with 45 CFR 46.101.

- This research study was granted an exemption because the Research involves educational tests, survey procedures, interview procedures or observation of public behavior and (i) information obtained is recorded in such a manner that human subjects cannot be identified, directly or through identifiers linked to the subjects; and (ii) any disclosure of the human subjects responses outside the research could not reasonably place the subjects at risk of criminal or civil liability or be damaging to the subjects financial standing, employability, or reputation [45 CFR 46.101(2)]. All exemptions are only good for three years. If this research extends more than three years beyond the approved date, then the researcher will have to request another exemption. The following documents have been acknowledged for use in this study and are available in the WVU+kc system:

Documents reviewed and/or approved as part of this submission:

Social Media Use, Celebrity-Endorsers and Purchase Intentions SURVEY.pdf: 2017-0113-05:00 
CONSENT Social Media Use, Celebrity-Endorsers and Purchase

Intentions SURVEY.pdf: 2017-01-13-05:00

Documents for use in this study have been acknowledged and are available in the WVUkc system in the Notes and Attachments section of your protocol.

The Office of Research Integrity and Compliance is here to provide assistance to you from the initial submission of an IRB protocol and all subsequent activity. Please feel free to contact us by phone at 304.293.7073 with any question you may have. Thank you.

WVU Office of Research Integrity

and Compliance Date:01/31/2017

Signed:

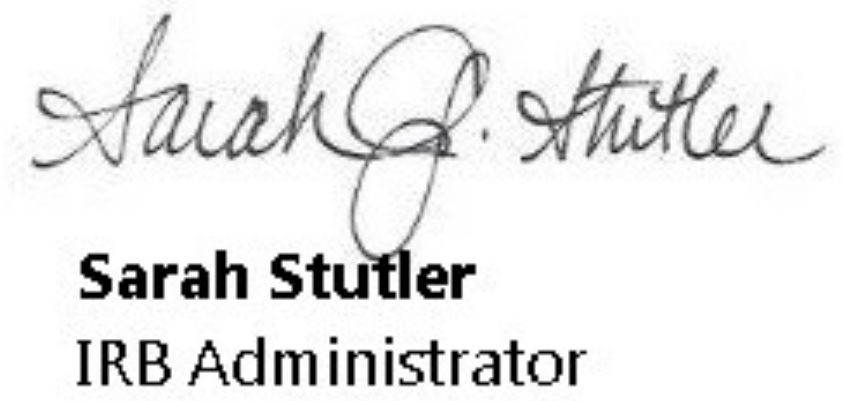




\section{Appendix B- Email Informed Consent Statement}

Dear Student,

I am currently a master's journalism student conducting research for my thesis exploring the relationship between Millennial's social media use, their interaction with celebrities on social media sites and their purchase intentions when exposed to celebrity-based endorsements. Please consider completing a confidential, 5 to 10minute online questionnaire on this topic focusing on your own social media use, interaction with celebrities and your purchase intentions.

There are no known risks associated with participation in this study, and WVU's institutional review board's acknowledgement of this project is on file (\#\#1610324997). You will receive extra credit for your class as a reward for taking part in this survey, so remember to please fill out your name, email and class information to get the extra credit. The survey will close on Wednesday, February 22 at 11:59 p.m. None of your personal contact or class information will be used for the data analysis, and it will remain strictly confidential. Anyone who is $\mathbf{1 8}$ or older may participate in the survey.

If you have any questions, please contact me at kmdavis1@mix.wvu.edu or the primary investigator Dr. Urbanski, who is an associate professor at the Reed College of Media, at Steve.Urbanski@mail.wvu.edu.

Here's the link: http://wvu.qualtrics.com/SE/?SID=SV bDdYQ6JqXHR3bUN (Note: If the questionnaire doesn't show up, please copy and paste the whole link into your browser)

Thank you so much for your valuable time!

Best,

Kaitlin Davis 


\title{
Appendix C- Survey Instrument
}

\author{
Social Media Use, Celebrity-Endorsers and Purchase Intentions
}

Q1 Thank you for agreeing to participate in this survey. For planning purposes, participation should take approximately 5 to 10 minutes of your time. It is important that once you begin you have allocated sufficient time to answer all questions because partially completed questionnaires cannot be used. This study is being conducted by a master student at West Virginia University. The purpose of this research is to see the effect that characteristics of celebrity endorsers have on purchasing intentions of social media users. Before you begin the survey, please read the information below and indicate whether you agree to participate in this study. Your participation is completely voluntary. All responses within the context of this study are completely confidential to ensure each participant's privacy. None of your answers to these questions will be attributed to you in the final manuscript. Results of each question will be compiled electronically by Qualtrics, the online survey system. By continuing, you are indicating that you are over the age of 18 , and wish to participate in this study.

Q2 For the purpose of this study, a celebrity endorser is any person that enjoys public recognition in coordination with a consumer good in an advertisement. Before proceeding on with the survey, please indicate your level of interest in celebrity endorsers or celebrities in general.

Not at all interested (1)

Not very interested (2)

O Somewhat interested (3)

Very interested (4)

If Not at all interested Is Selected, Then Skip To End of Survey

Q21 Please think of a recent celebrity-based endorsement that you saw on social media. For the following three questions, think of this particular endorsement and in a couple of sentences, describe the endorser, the product being endorsed and which social media platform you saw the endorsement on.

Q22 What celebrity was featured in the endorsement?

Q23 What product was the What celebrity was featured in the endorsement? endorsing? Please describe the product or brand to the best of your ability.

Q24 For the endorsement that What celebrity was featured in the endorsement? was featured in, which social media platform did you see this endorsement on? Please describe in a few short sentences. 
Q3 For this next question, please think about What celebrity was featured in the endorsement? whom acts as an endorser. Please indicate your level of agreement with the following statements: 


\begin{tabular}{|c|c|c|c|c|c|c|c|}
\hline & $\begin{array}{c}\text { Strongly } \\
\text { Disagre } \\
\text { e (1) }\end{array}$ & $\begin{array}{c}\text { Disagre } \\
\text { e (2) }\end{array}$ & $\begin{array}{c}\text { Somewha } \\
\text { t disagree } \\
\text { (3) }\end{array}$ & $\begin{array}{l}\text { Neither } \\
\text { agree } \\
\text { nor } \\
\text { disagre } \\
\text { e (4) }\end{array}$ & $\begin{array}{l}\text { Somewha } \\
\text { t agree (5) }\end{array}$ & $\begin{array}{l}\text { Agre } \\
\text { e (6) }\end{array}$ & $\begin{array}{c}\text { Strongl } \\
\text { y agree } \\
(7)\end{array}$ \\
\hline $\begin{array}{c}\text { I follow my } \\
\text { What celebrity } \\
\text { was featured } \\
\text { in the } \\
\text { endorsement? } \\
\text { on social } \\
\text { media (1) }\end{array}$ & 0 & 0 & $\mathrm{O}$ & 0 & 0 & 0 & 0 \\
\hline $\begin{array}{c}\text { I interact with } \\
\text { What celebrity } \\
\text { was featured } \\
\text { in the } \\
\text { endorsement?' } \\
\text { s social media } \\
\text { content (2) }\end{array}$ & 0 & $\mathrm{O}$ & 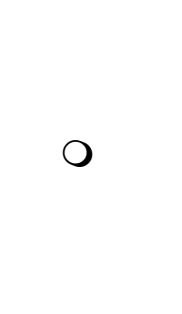 & 0 & 0 & 0 & 0 \\
\hline $\begin{array}{l}\text { I feel as } \\
\text { though I know } \\
\text { What celebrity } \\
\text { was featured } \\
\text { in the } \\
\text { endorsement? } \\
\text { (3) }\end{array}$ & 0 & 0 & 0 & 0 & 0 & 0 & 0 \\
\hline $\begin{array}{l}\text { I check What } \\
\text { celebrity was } \\
\text { featured in the } \\
\text { endorsement?' } \\
\text { s social media } \\
\text { accounts daily } \\
\text { (4) }\end{array}$ & 0 & 0 & O & 0 & 0 & 0 & $\bigcirc$ \\
\hline $\begin{array}{c}\text { I check What } \\
\text { celebrity was } \\
\text { featured in the } \\
\text { endorsement?' } \\
\text { s social media } \\
\text { accounts } \\
\text { weekly (5) }\end{array}$ & 0 & 0 & 0 & 0 & 0 & 0 & 0 \\
\hline $\begin{array}{c}\text { I check What } \\
\text { celebrity was } \\
\text { featured in the } \\
\text { endorsement?' } \\
\text { s media } \\
\text { accounts } \\
\text { monthly (6) }\end{array}$ & 0 & 0 & $\mathrm{O}$ & 0 & 0 & 0 & O \\
\hline
\end{tabular}




\begin{tabular}{|c|c|c|c|c|c|c|c|}
\hline $\begin{array}{l}\text { I pay attention } \\
\text { to the products } \\
\text { or brands that } \\
\text { What celebrity } \\
\text { was featured } \\
\text { in the } \\
\text { endorsement? } \\
\text { is endorsing } \\
\text { (7) }\end{array}$ & 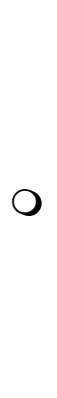 & 0 & 0 & 0 & 0 & 0 & 0 \\
\hline $\begin{array}{l}\text { I trust my } \\
\text { What celebrity } \\
\text { was featured } \\
\text { in the } \\
\text { endorsement?' } \\
\text { s opinion (8) }\end{array}$ & 0 & 0 & 0 & 0 & 0 & 0 & 0 \\
\hline $\begin{array}{l}\text { I want to be } \\
\text { like What } \\
\text { celebrity was } \\
\text { featured in the } \\
\text { endorsement? } \\
\text { (9) }\end{array}$ & 0 & 0 & 0 & 0 & 0 & 0 & 0 \\
\hline $\begin{array}{l}\text { I trust the } \\
\text { brands and } \\
\text { products that } \\
\text { What celebrity } \\
\text { was featured } \\
\text { in the } \\
\text { endorsement? } \\
\text { endorses (10) }\end{array}$ & 0 & 0 & 0 & 0 & 0 & 0 & 0 \\
\hline $\begin{array}{l}\text { I find myself } \\
\text { buying } \\
\text { specific } \\
\text { products the } \\
\text { What celebrity } \\
\text { was featured } \\
\text { in the } \\
\text { endorsement? } \\
\text { has endorsed } \\
\text { (11) }\end{array}$ & 0 & 0 & 0 & 0 & 0 & 0 & 0 \\
\hline $\begin{array}{l}\text { I find myself } \\
\text { buying } \\
\text { products from } \\
\text { brands that } \\
\text { What celebrity } \\
\text { was featured } \\
\text { in the } \\
\text { endorsement? } \\
\text { endorses (12) }\end{array}$ & 0 & 0 & 0 & 0 & 0 & 0 & 0 \\
\hline
\end{tabular}




\begin{tabular}{|c|c|c|c|c|c|c|c|}
\hline $\begin{array}{l}\text { I remember } \\
\text { What celebrity } \\
\text { was featured } \\
\text { in the } \\
\text { endorsement?' } \\
\text { s endorsement } \\
\text { when looking } \\
\text { at a specific } \\
\text { product or a } \\
\text { product from a } \\
\text { brand (13) }\end{array}$ & O & O & 0 & O & 0 & 0 & $\bigcirc$ \\
\hline
\end{tabular}

Q4 Keeping in mind What celebrity was featured in the endorsement?, please indicate your rating of What celebrity was featured in the endorsement? for each adjective pair if you saw some form of endorsement content from them.

\begin{tabular}{|c|c|c|c|c|c|c|c|}
\hline & $1(1)$ & $2(2)$ & $3(3)$ & $4(4)$ & $5(5)$ & $6(6)$ & $7(7)$ \\
\hline Inexpert:Expert (1) & $\mathrm{O}$ & $\mathrm{O}$ & O & $\mathrm{O}$ & $\mathrm{O}$ & $\mathrm{O}$ & $\mathrm{O}$ \\
\hline Inexperienced:Experienced (2) & $\mathrm{O}$ & $\mathrm{O}$ & $\mathrm{O}$ & $\mathrm{O}$ & $\mathrm{O}$ & O & $\mathrm{O}$ \\
\hline $\begin{array}{c}\text { Unknowledgeable:Knowledgeable } \\
\text { (3) }\end{array}$ & $\mathrm{O}$ & $\mathrm{O}$ & O & $\mathrm{O}$ & $\mathrm{O}$ & $\mathrm{O}$ & $\mathrm{O}$ \\
\hline Unqualified:Qualified (4) & $\mathrm{O}$ & $\mathrm{O}$ & O & $\mathrm{O}$ & $\mathrm{O}$ & O & $\mathrm{O}$ \\
\hline Unskilled:Skilled (5) & $\mathrm{O}$ & $\mathrm{O}$ & $\mathrm{O}$ & $\mathrm{O}$ & $\mathrm{O}$ & $\mathrm{O}$ & $\mathrm{O}$ \\
\hline Unfriendly:Friendly (6) & O & $\mathrm{O}$ & O & $\mathrm{O}$ & $\mathrm{O}$ & O & $\mathrm{O}$ \\
\hline Unpleasant:Pleasant (7) & $\mathrm{O}$ & $\mathrm{O}$ & $\mathrm{O}$ & $\mathrm{O}$ & $\mathrm{O}$ & $\mathrm{O}$ & $\mathrm{O}$ \\
\hline Unselfish:Selfish (8) & $\mathrm{O}$ & $\mathrm{O}$ & O & $\mathrm{O}$ & $\mathrm{O}$ & O & $\mathrm{O}$ \\
\hline Awful:Nice (9) & O & $\mathrm{O}$ & O & $\mathrm{O}$ & O & O & $\mathrm{O}$ \\
\hline Sinful:Virtuous (10) & $\mathrm{O}$ & $\mathrm{O}$ & $\mathrm{O}$ & $\mathrm{O}$ & $\mathrm{O}$ & $\mathrm{O}$ & $\mathrm{O}$ \\
\hline Unattractive:Attractive (11) & $\mathrm{O}$ & $\mathrm{O}$ & $\mathrm{O}$ & $\mathrm{O}$ & $\mathrm{O}$ & $\mathrm{O}$ & $\mathrm{O}$ \\
\hline Not beautiful:Beautiful (12) & $\mathrm{O}$ & $\mathrm{O}$ & $\mathrm{O}$ & $\mathrm{O}$ & $\mathrm{O}$ & $\mathrm{O}$ & $\mathrm{O}$ \\
\hline Not sexy:Sexy (13) & $\mathrm{O}$ & 0 & $\mathrm{O}$ & $\mathrm{O}$ & $\mathrm{O}$ & $\mathrm{O}$ & $\mathrm{O}$ \\
\hline Untrustworthy:Trustworthy (14) & $\mathrm{O}$ & $\mathrm{O}$ & O & $\mathrm{O}$ & $\mathrm{O}$ & $\mathrm{O}$ & $\mathrm{O}$ \\
\hline Unreliable:Reliable (15) & $\mathrm{O}$ & $\mathrm{O}$ & O & $\mathrm{O}$ & O & O & $\mathrm{O}$ \\
\hline Dishonest:Honest (16) & $\mathrm{O}$ & $\mathrm{O}$ & O & $\mathrm{O}$ & $\mathrm{O}$ & $\mathrm{O}$ & $\mathrm{O}$ \\
\hline Insincere:Sincere (17) & $\mathrm{O}$ & $\mathrm{O}$ & $\mathrm{O}$ & $\mathrm{O}$ & $\mathrm{O}$ & $\mathrm{O}$ & $\mathrm{O}$ \\
\hline Not influential:Influential (18) & $\mathrm{O}$ & $\mathrm{O}$ & 0 & $\mathrm{O}$ & $\mathrm{O}$ & 0 & $\mathrm{O}$ \\
\hline
\end{tabular}


Q5 In order to find out more about participant's online habits, we will ask a couple of questions addressing social media use. What social media platform do you use most often?

Facebook (1)

O Instagram (2)

Twitter (3)

O Youtube (4)

Other (please specify) (5)

Q6 On average, approximately how many hours do you spend on social media each day?

Q20 Approximately how many times a day do you check your social media accounts?

Q7 Approximately, how many followers do you have on twitter?

Q8 Approximately, how many celebrities do you follow on Twitter?

Q9 What is your gender?

Q10 How old are you?

Q11 What class rank are you currently?

O Freshman (1)

O Sophmore (2)

O Junior (3)

O Senior (4)

Graduate (5)

Q13 What is your racial background?

Q19 The following two questions will ask for both your name and email. None of this information will be used for the data analyzation and it will remain strictly confidential. This information is just needed to ensure that participants get the extra credit for participating in the survey.

Q15 What is your name?

Q17 What is your email?

Q14 Thank you for participating in this study. Do you have any thoughts, suggestions, or comments related to the study that you would like to share? If so, please add them in the box provided. 